\title{
Distribution and Bioconcentration of Polycyclic Aromatic Hydrocarbons in Surface Water and Fishes
}

\author{
Haiyan Li1,2 and Yong Ran ${ }^{1}$ \\ ${ }^{1}$ State Key Laboratory of Organic Geochemistry, Guangzhou Institute of Geochemistry, Chinese Academy of Sciences, \\ Wushan, Guangzhou 510640, China \\ ${ }^{2}$ University of Chinese Academy of Sciences, Beijing 100049, China
}

Correspondence should be addressed to Yong Ran, yran@gig.ac.cn

Received 4 October 2012; Accepted 10 December 2012

Academic Editors: Y. Shimizu and F.-L. Xu

Copyright (C) 2012 H. Li and Y. Ran. This is an open access article distributed under the Creative Commons Attribution License, which permits unrestricted use, distribution, and reproduction in any medium, provided the original work is properly cited.

\begin{abstract}
To examine spatial distribution and bioconcentration of PAHs, water and fish samples were collected from Pearl River Delta in summer and spring, respectively. Particulate organic carbon, dissolved organic carbon, biodegradable DOC (BDOC), and chlorophyll a were measured. PAHs were dominated by 2- and 3-ring compounds in the water and SPM samples. Aqueous and solid-phase PAHs, respectively, showed significant correlations with total organic matter (TOC) in SPM or dissolved organic matter (DOC) in the water. The in-situ partitioning coefficients $\left(\log K_{\mathrm{oc}}, \mathrm{mL} / \mathrm{g}\right)$ for the samples were observed to be related to $\log K_{\mathrm{ow}}$, implying that the hydrophobicity of PAHs is a critical factor in their distribution. It was also observed that BCF increased with the increasing $K_{\mathrm{ow}}$ in the viscera of tilapia $\left(\log \mathrm{BCF}=0.507 \log K_{\mathrm{ow}}-1.368, r=0.883\right)$. However, most of the observed $\log \mathrm{BCF}$ values in other different fish tissues at first increased with the increasing of $\log K_{\mathrm{ow}}$, then reached a maximum value when $\log K_{\mathrm{ow}}$ is between 5 and 7, and then decreased when $\log K_{\text {ow }}$ is higher than 7, indicating that the value of BCF may vary due to the diversity of fish species.
\end{abstract}

\section{Introduction}

Polycyclic aromatic hydrocarbons (PAHs), which are listed as US-EPA and EU priority pollutants, are widely distributed in the environment. PAHs are produced primarily as a result of incomplete combustion of fossil fuels and other organic materials, as well as from forest fires [1]. PAHs in seawater depend on their chemical properties. PAHs with low molecular weight can enter atmosphere by evaporation, while nonvolatile PAHs with high molecular weight could contaminate surface water through atmospheric deposition [2]. Due to their carcinogenic and mutagenic effects to both terrestrial and aquatic organisms, PAHs have attracted much attention.

Many investigations focus on the transport and fate of PAHs in aquatic environment [3]. Qiu et al. [4] examined the level of 15 PAHs in seawater, suspended particulate matter (SPM), surface sediment, and core sediment samples of Deep Bay, South China. Recently, distributions, composition, and sources of polycyclic aromatic hydrocarbons (PAHs) in sediments and suspended particulate matter (SPM) from the Pearl River Delta have also been evaluated $[5,6]$. Major environmental factors in mediating PAH levels in the sediments as well as bioaccumulation patterns in fish were identified at Mai Po Marshes [7].

Although numerous studies have investigated the occurrence of PAHs in various compartments of the PRD, data on fish species are limited $[8,9]$. PAHs in fish tissues, for example, fish liver, skin, or gills, which could provide more evidence for the bioaccumulation of PAHs and reflect the environmental conditions, have not been investigated. Previous investigations in Pearl River Delta mainly focused on the source, distribution, migration, and fate of PAHs. However, their environmental processes such as the transformation and enrichment of PAHs have rarely been conducted.

The Pearl River Delta (PRD) has three main tributaries, which are the Xijiang (West) River, the Beijiang (North) River, and the Dongjiang (East) River, and flow into the South China Sea. They form one of the largest rivers in China. PRD endures a significant urbanization and industrialization in recent three decades. It is located in the northern subtropical zone, where the climate is characterized by mild temperatures and frequent rainfalls all years around, 


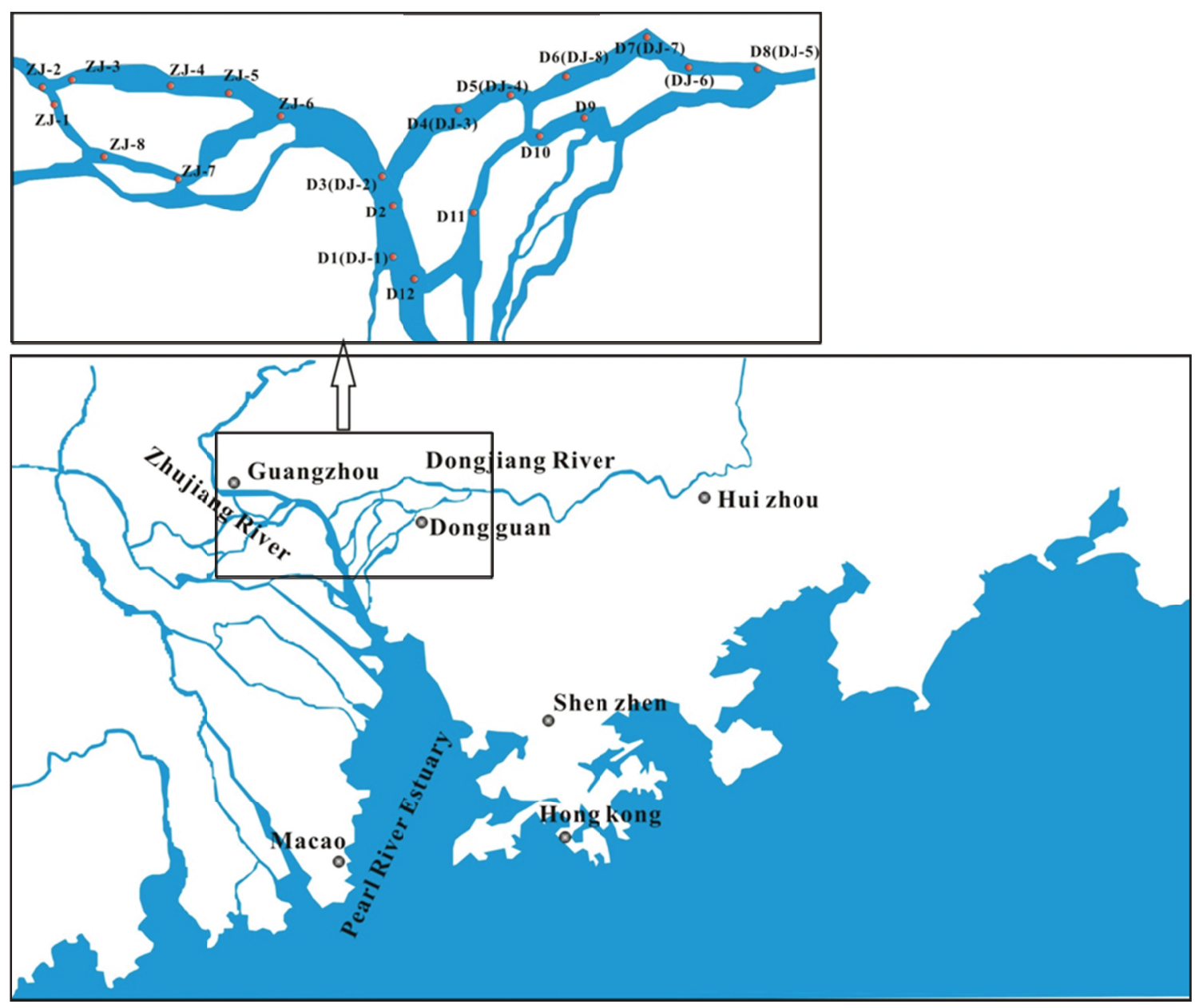

FIGURE 1: The sampling sites of the rivers from the Pearl River system.

facilitating the transport of contaminants to the aquatic environments. Owing to high population density, massive use of chemicals, and intensive industrial and agricultural development in this area, significant air and water pollutions occur $[10,11]$. With dramatic increase in aquatic environment pollutions in this region, the local fishery resource, biomass, and biodiversity decline continuously. For example, fish species in the Pearl River Estuary sharply decreased from more than 200 species in 1970 s to 50 species in recent years, and the proportion of the large size fish dropped from nearly $50 \%$ in 1980 s to lower than $10 \%$ in this century $[8,12]$.

The present study aimed to determine the spatial distribution and partitioning of PAHs in water/SPM and the affecting factors, and the distribution and accumulation of PAHs in different species of fishes in order to evaluate the enrichment regularities of PAHs among water, SPM, and fish organisms.

\section{Materials and Methods}

2.1. Sample Collection. Water and SPM samples at $0.5 \mathrm{~m}$ below the surface were collected from Pearl River Delta in July 2010 and April 2011, respectively (Figure 1). Meanwhile fish samples were collected at site D7 (xenocypris davidi, Bleeker) and site D8 (tilapia, blunt snout bream, Cirrhinus mrigala) in July, 2010, and at site DJ-5 (red grass carp, blunt snout bream named as blunt snout bream-2, carp) in April 2011. Water samples were pumped into precleaned $10 \mathrm{~L}$ brown glass bottles with a stainless-steel submersible pump. $\mathrm{NaN}_{3}$ was added to each bottle to inhibit biodegradation of PAHs. $\mathrm{pH}$, conductivity, and salinity were measured immediately at the sites by using a digital $\mathrm{pH}$ meter with dissolved oxygen meter and salinometer (MP511,Shanghai). All of the parameters are listed in Tables 1 and 2. Some of the fish samples were also bought from small fishing boats along the river. The water samples were filtered through the $47 \mathrm{~mm}$ glass fiber filters (Whatman GF/F, 0.7 um pore sizes) precombusted at $450^{\circ} \mathrm{C}$ for $4 \mathrm{~h}$ beforehand. Then, the GF/F filters were stored at $-20^{\circ} \mathrm{C}$ until analysis. Fish samples were dissected carefully to obtain muscles, gills, and viscera. These samples were also stored at $-20^{\circ} \mathrm{C}$ until analysis.

2.2. Chemicals. HPLC-grade methanol $(\mathrm{MeOH})$, hexane (Merck), ethyl acetate (Sigma), redistilled water, and analytical grade dichloromethane (DCM) and acetone were used for the analysis. Sixteen PAHs standards and deuterated 
TABLE 1: Major aquatic chemical properties of the water samples collected from Dongjiang River in July 2010.

\begin{tabular}{|c|c|c|c|c|c|c|c|}
\hline \multirow{2}{*}{ Station } & \multirow{2}{*}{$\mathrm{DOC}(\mathrm{mg} / \mathrm{L})$} & \multirow{2}{*}{$\mathrm{BDOC}(\mathrm{mg} / \mathrm{L})$} & \multirow{2}{*}{ POC\% } & \multirow{2}{*}{ Chl a $\mu \mathrm{g} / \mathrm{L}$} & \multirow{2}{*}{ SPM (mg/L) } & \multicolumn{2}{|c|}{ Total PAHs (ng/L) } \\
\hline & & & & & & Dissolved & Particulate \\
\hline D-1 & 10.20 & 7.32 & 8.49 & 3.11 & 20 & 16.56 & 116.49 \\
\hline D-2 & 2.71 & 0.75 & 9.46 & 4.81 & 31 & 20.24 & 229.82 \\
\hline $\mathrm{D}-3$ & 13.91 & 10.9 & 4.93 & 6.14 & 34 & 21.10 & 321.68 \\
\hline D-4 & 1.19 & -0.23 & 13.3 & 4.53 & 53 & 31.97 & 360.14 \\
\hline D-5 & 2.28 & 0.49 & 4.14 & 4.62 & 33 & 27.99 & 91.35 \\
\hline D-6 & 3.45 & 1.33 & 6.29 & 4.29 & 20 & 34.27 & 30.14 \\
\hline $\mathrm{D}-7$ & 1.93 & -0.408 & 4.44 & 3.39 & 16 & 33.91 & 252.75 \\
\hline D-8 & 2.11 & 0.555 & 4.76 & 3.43 & 12 & 25.89 & 25.57 \\
\hline D-9 & 1.85 & 0.017 & 5.67 & 3.18 & 11 & 23.26 & 41.36 \\
\hline D-10 & 2.77 & 0.771 & nd & 3.53 & 11 & 24.19 & 32.82 \\
\hline D-11 & 2.63 & 0.705 & 5.44 & 10.1 & 17 & 28.80 & 38.83 \\
\hline D-12 & 3.18 & 0.652 & 5.10 & 5.22 & 27 & 19.37 & 37.50 \\
\hline
\end{tabular}

TABle 2: Major aquatic chemical properties of the water samples in April 2011.

\begin{tabular}{|c|c|c|c|c|c|c|c|c|c|c|c|c|}
\hline \multirow{2}{*}{ Station } & \multirow{2}{*}{ Location } & \multirow{2}{*}{$\mathrm{PH}$} & \multirow{2}{*}{$\begin{array}{l}\text { COND } \\
\mu \mathrm{s} / \mathrm{cm}\end{array}$} & \multirow{2}{*}{$\begin{array}{l}\text { SAL } \\
(\mathrm{ppt})\end{array}$} & \multirow{2}{*}{$\begin{array}{c}\mathrm{DO} \\
(\mathrm{mg} / \mathrm{L})\end{array}$} & \multirow{2}{*}{$\begin{array}{c}\text { DOC } \\
(\mathrm{mg} / \mathrm{L})\end{array}$} & \multirow{2}{*}{$\begin{array}{l}\text { BDOC } \\
(\mathrm{mg} / \mathrm{L})\end{array}$} & \multirow{2}{*}{$\mathrm{POC} \%$} & \multirow{2}{*}{$\begin{array}{l}\text { Chl a } \\
\mu \mathrm{g} / \mathrm{L}\end{array}$} & \multirow{2}{*}{$\begin{array}{c}\text { SPM } \\
(\mathrm{mg} / \mathrm{L})\end{array}$} & \multicolumn{2}{|c|}{$\sum_{15}$ PAHs $(\mathrm{ng} / \mathrm{L})$} \\
\hline & & & & & & & & & & & Dissolved & Particulate \\
\hline DJ-1 & $\begin{array}{l}23^{\circ} 01.372 \mathrm{~N} \\
113^{\circ} 30.873 \mathrm{E}\end{array}$ & 6.92 & 2280 & 0.62 & 3.93 & 3.71 & 1.11 & 4.74 & 28.2 & 24.00 & 11.11 & 97.91 \\
\hline DJ-2 & $\begin{array}{c}23^{\circ} 03.161 \mathrm{~N} \\
113^{\circ} 31.580 \mathrm{E}\end{array}$ & 6.94 & 1244 & 0.61 & 3.34 & 4.01 & 0.777 & 6.86 & 21.2 & 23.65 & 12.06 & 93.0 \\
\hline DJ-3 & $\begin{array}{c}23^{\circ} 05.685 \mathrm{~N} \\
113^{\circ} 35.399 \mathrm{E}\end{array}$ & 6.96 & 327 & 0.16 & 1.72 & 5.24 & 3.06 & 7.08 & 21.7 & 22.32 & 65.21 & 114.9 \\
\hline DJ-4 & $\begin{array}{c}23^{\circ} 06.672 \mathrm{~N} \\
113^{\circ} 38.957 \mathrm{E}\end{array}$ & 6.9 & 255 & 0.12 & 2.42 & 5.38 & 3.08 & 9.65 & 3.87 & 13.65 & 46.32 & 80.2 \\
\hline DJ-5 & $\begin{array}{c}23^{\circ} 07.115 \mathrm{~N} \\
113^{\circ} 50.281 \mathrm{E}\end{array}$ & 7.03 & 177 & 0.08 & 6.60 & 2.42 & 0.902 & 1.59 & 2.93 & 42.86 & 27.48 & 80.1 \\
\hline DJ-6 & $\begin{array}{c}23^{\circ} 07.843 \mathrm{~N} \\
113^{\circ} 45.988 \mathrm{E}\end{array}$ & 6.92 & 199 & 0.1 & 7.06 & 3.00 & 1.40 & 1.80 & 2.76 & 34.24 & 11.46 & 65 \\
\hline DJ-7 & $\begin{array}{c}23^{\circ} 08.121 \mathrm{~N} \\
113^{\circ} 44.895 \mathrm{E}\end{array}$ & 6.76 & 166 & 0.08 & 6.67 & 2.28 & 0.613 & 1.64 & 2.76 & 24.97 & 14.83 & 53.5 \\
\hline DJ-8 & $\begin{array}{c}23^{\circ} 08.731 \mathrm{~N} \\
113^{\circ} 43.746 \mathrm{E}\end{array}$ & 6.51 & 179 & 0.08 & 6.00 & 2.62 & 1.06 & 2.29 & 3.30 & 14.72 & 12.75 & 103.6 \\
\hline ZJ-1 & & 7.23 & 867 & 0.43 & 4.68 & 4.79 & 0.889 & 8.87 & 40.7 & 42.26 & 44.21 & 191.6 \\
\hline ZJ-2 & & 7.16 & 814 & 0.37 & 5.56 & 4.88 & 0.883 & 14.6 & 48.3 & 46.87 & 38.71 & 223.2 \\
\hline ZJ-3 & & 7.32 & 660 & 0.32 & 5.98 & 4.41 & 0.700 & 7.36 & 41.9 & 36.56 & 40.54 & 191.9 \\
\hline ZJ-4 & & 7.26 & 696 & 0.33 & 5.6 & 3.60 & 0.415 & 4.05 & 45.1 & 42.10 & 27.34 & 229.2 \\
\hline ZJ-5 & & 7.2 & 649 & 0.32 & 5.68 & 3.02 & 0.438 & 4.24 & 31.3 & 19.96 & 21.84 & 80.8 \\
\hline ZJ-6 & & 7.08 & 957 & 0.48 & 6.28 & 2.81 & 0.563 & 5.00 & 26.4 & 26.32 & 22.59 & 105.5 \\
\hline ZJ-7 & & 7.24 & 618 & 0.3 & 6.38 & 2.62 & 0.421 & 4.51 & 16.2 & 22.49 & 20.43 & 92.1 \\
\hline ZJ-8 & & 7.21 & 492 & 0.25 & 6.49 & 2.62 & 0.441 & 4.81 & 20.9 & 30.44 & 36.49 & 151.7 \\
\hline
\end{tabular}

PAHs (naphthalene- $\mathrm{d}_{8}$, acenaphthene- $\mathrm{d}_{10}$, phenanthrene$d_{10}$, chrysene- $d_{12}$, and perylene- $d_{12}$ ) were purchased from Ultra Scientific Inc. Hexamethylbenzene was purchased from Aldrich. ENVI-C 18 SPE cartridges $(500 \mathrm{mg}, 6 \mathrm{~mL}$ ) were obtained from Supelco (Bellefonte, PA, USA), and glass fiber filters (GF/F, $0.7 \mu \mathrm{m}$ pore size) were purchased from Whatman (Maidstone, England). Neutral silica gel (80100 mesh) and alumina (100-200 mesh) were extracted with DCM for $72 \mathrm{~h}$ and activated at $120^{\circ} \mathrm{C}$ and $180^{\circ} \mathrm{C}$ for $12 \mathrm{~h}$, respectively. And then they were deactivated by adding 3\% redistilled water. Anhydrous sodium sulfate, glasswares, and glass fiber filters were baked at $450^{\circ} \mathrm{C}$ for 4 hours prior to use.

2.3. Analytical Procedure. The procedures for the extraction and purification of PAHs from water, suspended particulate matter (SPM), and fish samples were published elsewhere [5, 12-14]. In brief, $4 \mathrm{~L}$ filtered water was spiked with deuterated internal standards (naphthalene- $\mathrm{d}_{8}$, acenaphthene- $\mathrm{d}_{10}$, 
phenanthrene- $\mathrm{d}_{10}$, chrysene- $\mathrm{d}_{12}$, and perylene- $\left.\mathrm{d}_{12}\right)$. The Envi- $\mathrm{C}_{18}$ SPE cartridge was sequentially conditioned with $5 \mathrm{~mL}$ of ethyl acetate, $5 \mathrm{~mL}$ of methanol, and $5 \mathrm{~mL}$ distilled water containing $2 \%$ methanol. Then, the water sample passed through the preconditioned Envi- $\mathrm{C}_{18}$ SPE cartridge at a flow rate of $8-10 \mathrm{~mL} / \mathrm{min}$. The cartridge was cleaned with $5 \mathrm{~mL}$ distilled water, dried under vacuum for 15 minutes, and eluted with $3 \times 5 \mathrm{~mL}$ of ethyl acetate. Finally the elution was vacuum-evaporated to $1 \mathrm{~mL}$ and concentrated to $100 \mu \mathrm{L}$ under a gentle nitrogen stream.

Particle-loaded filters were freeze dried, weighed, and spiked with surrogate standards and Soxhlet extracted for $72 \mathrm{~h}$ with $200 \mathrm{~mL}$ of dichloromethane (DCM). Each extract was concentrated, solvent exchanged to hexane, and reduced to approximately $1 \mathrm{~mL}$. A 1:2 alumina: silica gel glass column was used to purify the concentrated extracts. Then, the column was eluted with $15 \mathrm{~mL}$-hexane and $70 \mathrm{~mL} 7: 3$ hexane/DCM (v/v) successively. The second fraction containing PAHs was also finally concentrated to $100 \mu \mathrm{L}$ under a gentle $\mathrm{N}_{2}$ stream before GC/MS analysis.

Fish tissue samples were freeze dried, spiked with surrogate standards, and Soxhlet extracted for $72 \mathrm{~h}$ with $200 \mathrm{~mL}$ of dichloromethane (DCM). Each extract was concentrated to about $5 \mathrm{~mL}$ and divided into two fractions. One fraction was used to determine the content of lipid by weight method, and the remaining fraction was used to determine the concentration of PAHs in fish tissue. The remaining fraction passed through a gel permeation column to remove lipid. The elution solvent from 90 to $280 \mathrm{~mL}$ was collected and concentrated by a rotary evaporator. Then, the concentration extract was again cleaned by an alumina/silica gel column. And the subsequent analytical procedure was the same as that of SPM. The fraction containing PAHs was also finally concentrated to $100 \mu \mathrm{L}$ before GC/MS analysis.

2.4. Instrumental Analysis. Sixteen PAHs were quantified by a Hewlette Packard (HP) 6890 gas chromatograph (GC) coupled to a HP 5975 mass spectrometer (MS) with a DB5 fused silica capillary column $(30 \mathrm{~m} \times 0.25 \mu \mathrm{m} \times 0.25 \mathrm{~mm}$ i.d.). The system was operated in electron impact mode (EI) and detected by using selective ion monitoring mode (SIM) with helium as the carrier gas at a constant flow rate of $1 \mathrm{~mL} / \mathrm{min}$. The oven temperature was programmed from $60^{\circ} \mathrm{C}$ to $200^{\circ} \mathrm{C}$ at $10^{\circ} \mathrm{C} / \mathrm{min}$, to $214^{\circ} \mathrm{C}$ at a rate of $2^{\circ} \mathrm{C} / \mathrm{min}$ and to $255^{\circ} \mathrm{C}$ at $5^{\circ} \mathrm{C} / \mathrm{min}$ and held for $2 \mathrm{~min}$ and further increased to $290^{\circ} \mathrm{C}$ at $20^{\circ} \mathrm{C} / \mathrm{min}$ and held at $290^{\circ} \mathrm{C}$ for $12 \mathrm{~min}$. The concentrations of PAHs in the water and suspended particle matter were quantified by using the isotope dilution method with isotope-labeled internal standards ( $\mathrm{d} 8$ Nap, d10-Acy, d10-Phe, d12-Chry, and d12-Per). PAHs in fish tissues were quantified with the internal calibration method based on five-point calibration curve.

Ten $\mathrm{mL}$ of each water sample passed through the GF/F filter was acidified with $\mathrm{HCl}$ to $\mathrm{pH}=3$ and then used for DOC analysis. TOC analyzer (TOC-VCPH, Shimadzu) was used to measure the DOC concentration. For the determination of TOC in SPM samples, the filters were dried at $60^{\circ} \mathrm{C}$ for $12 \mathrm{~h}$ after acidification with diluted $\mathrm{HCl}$ to remove carbonates. TOC in particle samples was measured using an elemental analyzer (Vario EL III Elementar, Germany) with acetanilide as external standard. For the determination of biodegradable DOC (BDOC), approximately $300 \mathrm{~mL}$ of filtered water was contained into $500 \mathrm{~mL}$ precombusted brown glass bottles and incubated in the dark at about $20^{\circ} \mathrm{C}$ for $30 \mathrm{~d}$. The difference of DOC concentrations measured before and after incubation were regarded as the BDOC concentrations.

Samples for determining Chl a were filtered through 0.45 um cellulose acetate filters, and then the membrane samples were extracted with $90 \%$ acetone for $24 \mathrm{~h}$. Chl a was determined by using a UV-VIS spectrophotometer (752, UV2000, Shanghai). The absorbency at wavelength of $663 \mathrm{~nm}$, $645 \mathrm{~nm}, 663 \mathrm{~nm}$, and $750 \mathrm{~nm}$ were measured. Chl a was calculated by the following equation [15]:

$$
\begin{aligned}
C=[ & 11.64 \times(\mathrm{D} 663-\mathrm{D} 750)-2.16 \times(\mathrm{D} 645-\mathrm{D} 750) \\
& +0.1 \times(\mathrm{D} 630-\mathrm{D} 750)] \times \frac{V_{1}}{(V \times L)}
\end{aligned}
$$

where D630, D645, D663, and D750 represent the absorbency of $630,645,663$, and $750 \mathrm{~nm}$, respectively. The $V_{1}, V$, $L$, and $C$ represent the volume of water samples $(L)$, the thickness of cuvette $(\mathrm{cm})$, and the concentration of chlorophyll a $(\mu \mathrm{g} / \mathrm{L})$, respectively.

2.5. Quality Assurance and Quality Control (QA/QC). Procedural blanks and spiked blanks were analyzed with field samples, and surrogate standards (d8-Nap, d10-Acy, d10Phe, d12-Chry, and d12-Per) were also added to all the samples to monitor procedural performance. Except for Nap, $10.05 \mathrm{ng} / \mathrm{L}$ of total PAHs was detected on average in water blanks $(n=4)$, and $17.21 \mathrm{ng} / \mathrm{L}$ of total PAHs was detected in particle blanks $(n=5)$. The recoveries of 16 PAHs in spiked blanks ( $n=3$ ) varied from $50.9 \%$ (Nap) to $122.7 \%$ (BgP). Because of the high background values for Nap, total concentrations of PAHs did not include Nap. Phe was also not considered in the distribution of total PAHs in water and SPM samples due to the possible pollution during the process of experiments. And the reported PAHs concentrations were corrected with the blank values.

\section{Results and Discussions}

3.1. Major Properties of Water. The major aquatic chemical properties in the water samples including $\mathrm{pH}$, conductivity, salinity, dissolved oxygen (DO), concentration of suspended particulate matters (SPM), dissolved organic carbon (DOC), particulate organic matters (POC), chlorophyll a (Chl a), and total PAHs were listed in Tables 1 and 2. The concentrations of DOC in the Dongjiang River ranged from $1.19 \mathrm{mg} / \mathrm{L}$ to $13.91 \mathrm{mg} / \mathrm{L}$ in July 2010. While in April 2011, the DOC concentrations varied from $2.28 \mathrm{mg} / \mathrm{L}$ to $5.38 \mathrm{mg} / \mathrm{L}$ in the Dongjiang River and from 2.62 to $4.88 \mathrm{mg} / \mathrm{L}$ in the Pearl River. In the Dongjiang River, SPM, POC, and Chl a varied from 11 to $53 \mathrm{mg} / \mathrm{L}$, from $4.14 \%$ to $13.3 \%$, and from 3.11 to $10.1 \mu \mathrm{g} / \mathrm{L}$, respectively in July 2010 , while they ranged from 13.65 to $42.86 \mathrm{mg} / \mathrm{L}$, from $1.59 \%$ to $9.65 \%$, and from 2.76 to $28.2 \mu \mathrm{g} / \mathrm{L}$ in April 2011. Meanwhile, the SPM, POC, and Chl a concentrations in the samples collected from Pearl River in 


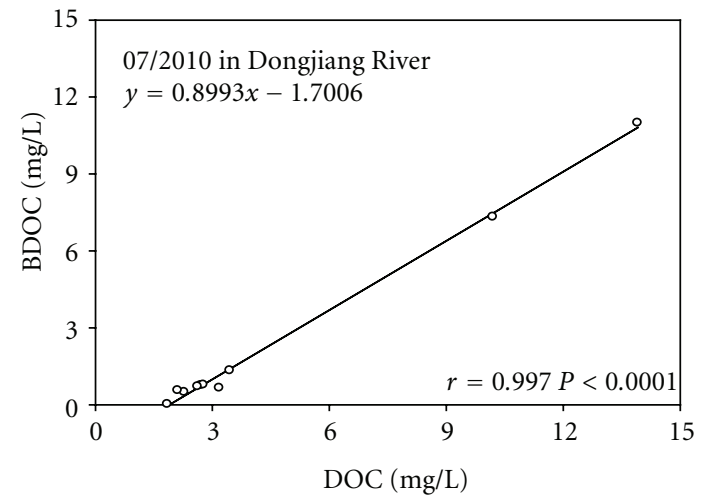

(a)

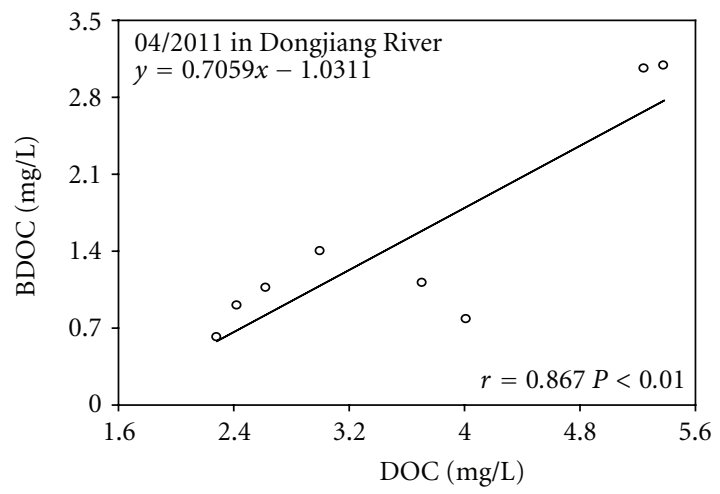

(b)

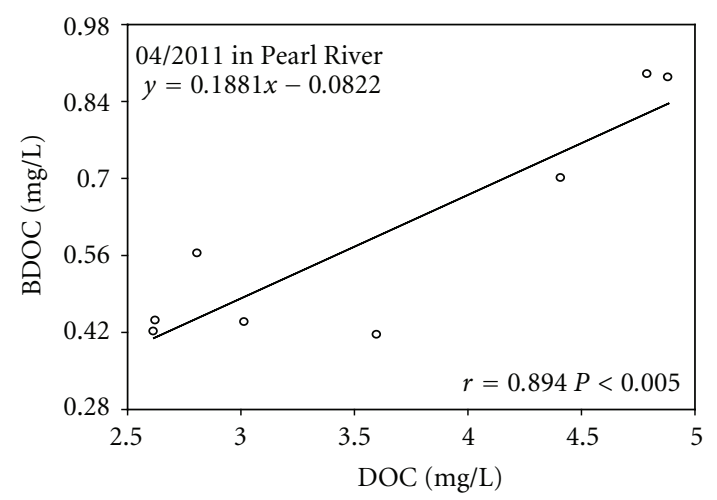

(c)

Figure 2: Correlations of DOC with BDOC of PAHs in Pearl River Delta.

April 2011 ranged from 19.96 to $46.87 \mathrm{mg} / \mathrm{L}$, from $4.05 \%$ to $14.6 \%$, and from 16.2 to $48.3 \mu \mathrm{g} / \mathrm{L}$.

The POC distribution shows a similar pattern with the distribution of chlorophyll a (Figure 3), indicating that phytoplankton plays an important role in POC pool. Besides, the concentrations of BDOC illustrate a linear and positive relationship with the initial DOC concentrations (Figure 2), suggesting that DOC was highly biodegradable within the time scale of the incubation ( 1 month). Chl a concentrations were also related to the PAHs concentrations (Figure 3 ), which indicated that PAHs can be easily absorbed by algae in the SPM. It was also implied that algae was the dominant composition of POC and governed the distribution of particulate PAHs. An increasing phytoplankton biomass and growth rate was reported to increase the air-water transfer of PAHs [16]. New phytoplankton production contributed to substantially longer times for air-water equilibrium, and the depletion of the dissolved phase by phytoplankton uptake prevented the equilibrium of air and water phases. The gas phase supports the concentrations of organic pollutants such as PAHs in atmospherically driven environments. Increased air-water exchange followed by phytoplankton uptake also seemed to be two of the most relevant processes increasing the vertical flux in the water column [17].

\subsection{Concentrations of PAHs in the Water, SPM, Fish, Lipid Samples}

3.2.1. PAHs in the Water Samples. PAHs in the water and SPM samples were listed in Figure 4. For the water samples, PAHs showed obviously seasonal variation in the Dongjiang River. They were higher in summer, ranging from 16.56 to $34.27 \mathrm{ng} / \mathrm{L}$ with an average of $25.63 \mathrm{ng} / \mathrm{L}$, than in spring, ranging from 11.11 to $65.21 \mathrm{ng} / \mathrm{L}$ with an average of $25.15 \mathrm{ng} / \mathrm{L}$.

Individual PAHs also showed considerable variances among the samples (Figure 5). For all the water samples, low molecular weight PAHs were the dominate compounds. The percentage of 3 and 4-ring PAHs ranged from $42.06 \%$ to $81.09 \%$ with an average of $65.38 \%$. Acenaphthylene, fluorene, fluoranthene, and pyrene were the major constituents of PAHs in the water samples.

PAHs in the water samples are compared with those of other investigations (Table 3 ). The total concentration of PAHs was 2 to 3 orders of magnitude lower than those reported in Daya Bay, China (4181-27507 ng/L) [18], Jiulong River Estuary, and Western Xiamen Sea, China (6840$25620 \mathrm{ng} / \mathrm{L}$ ) [19] and approximately 2 orders of magnitude lower than those found in Pearl River and the Macao Harbor, China (691-6457 ng/L) [20]. However, high PAHs in the Pearl River and the Macao Harbor [20] were related to the contamination of naphthalene in the laboratory, which accounted for about $90 \%$ of the total PAHs in dissolved phase. The aqueous concentrations in this study are similar to those of the previous investigations if Nap is excluded (13.64-106.85 ng/L). On the other hand, PAHs in this investigation were several times higher than those found in Beltic Sea (3.85-14.1 ng/L) and in the North Sea (0.63-3.51 ng/L) [21]. Similar concentrations were found in Xijiang River, China (21.7-138 ng/L) [5], Pearl River Delta (10.8-323 ng/L) [14], and Chesapeake Bay, USA (20-65.7 ng/L) [22].

3.2.2. PAHs in SPM. PAHs in SPM presented in Figure 4 also showed seasonal variation like PAHs of the water samples in the Dongjiang River. The total PAHs concentrations varied from 30.14 to $360.14 \mathrm{ng} / \mathrm{L}$ with an average of $131.5 \mathrm{ng} / \mathrm{L}$ and a standard deviation of $124.8 \mathrm{ng} / \mathrm{L}$ in summer and from 53.45 to $114.9 \mathrm{ng} / \mathrm{g}$ with an average of $85.77 \mathrm{ng} / \mathrm{g}$ and a standard deviation of $20.68 \mathrm{ng} / \mathrm{L}$ in spring. In the Pearl River, particulate PAHs were in a range of 80.8 to $229.2 \mathrm{ng} / \mathrm{L}$ with an average of $158.24 \mathrm{ng} / \mathrm{L}$ and a standard deviation of $59.4 \mathrm{ng} / \mathrm{L}$. 


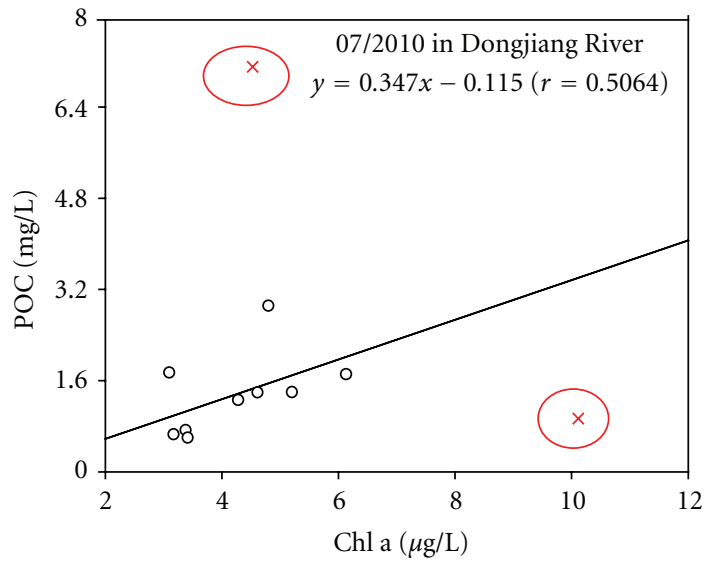

(a)

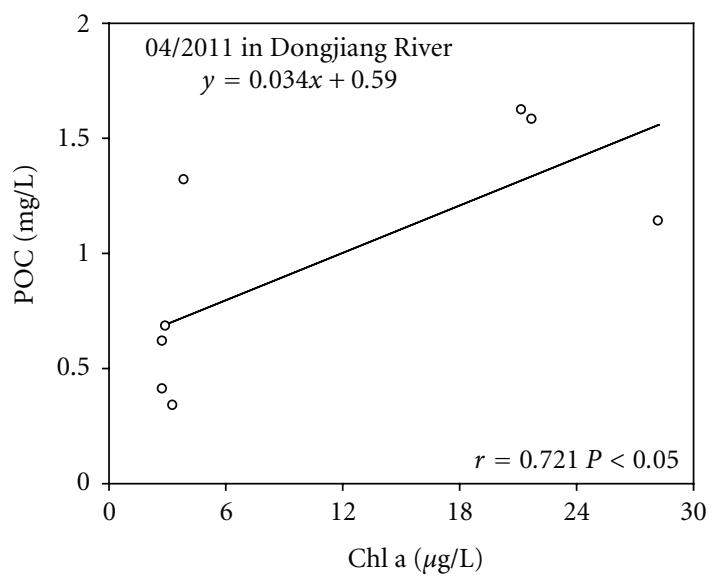

(c)

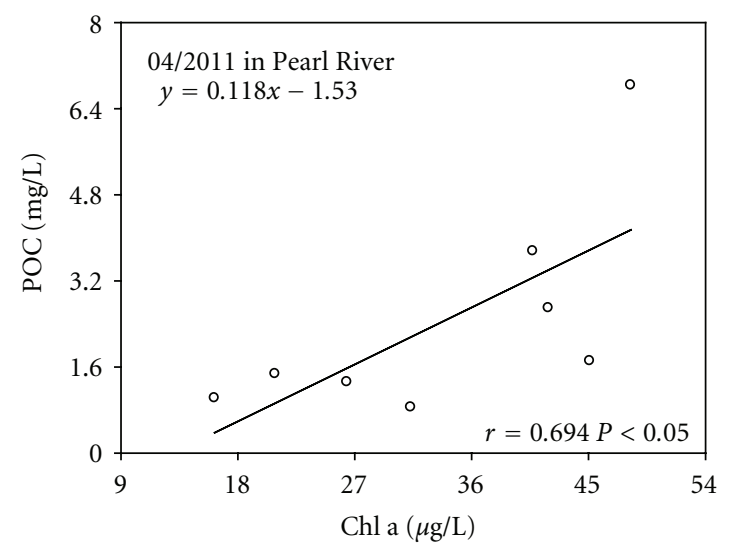

(e)

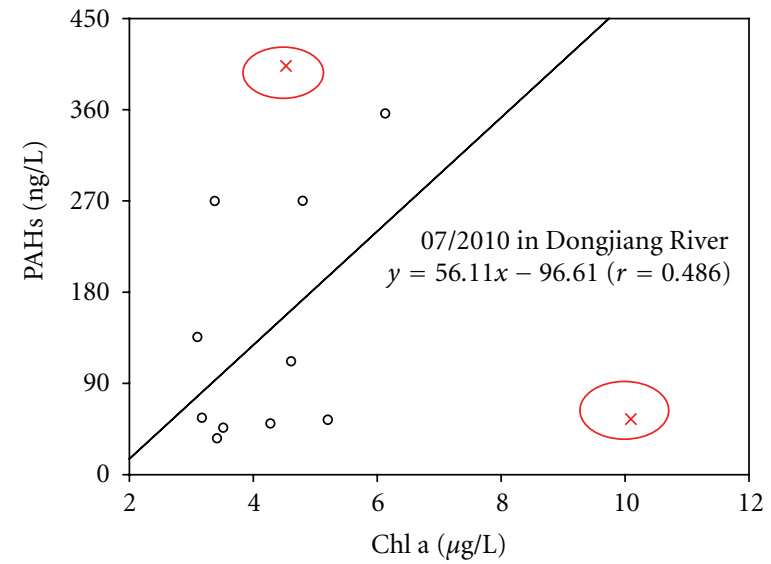

(b)

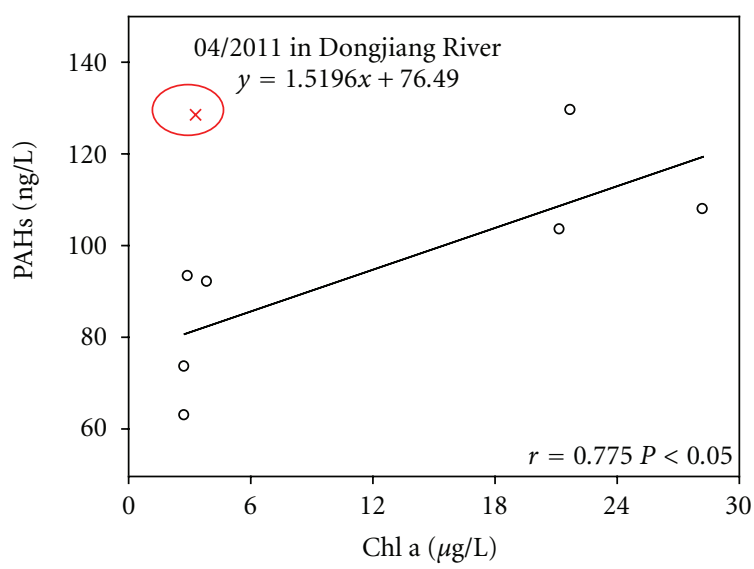

(d)

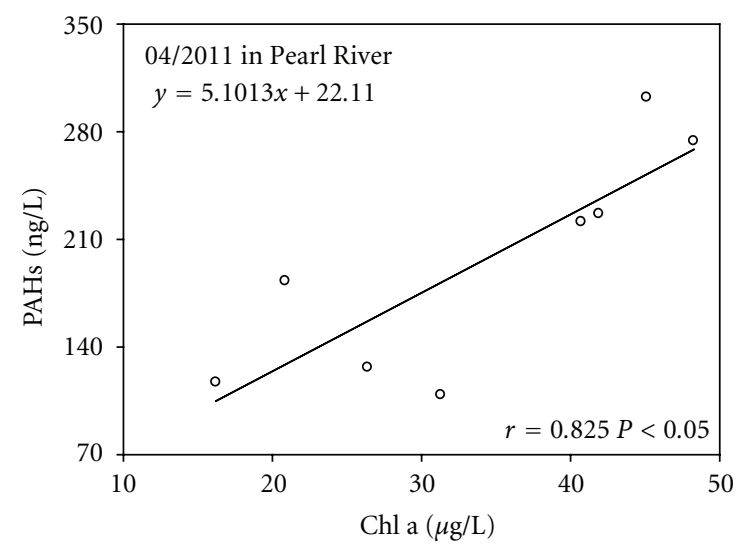

(f)

Figure 3: Relationship between Chl a and POC and between particulate PAHs (S-PAHs) and Chl a.

It was found that PAHs in SPM was higher in Pearl River than in Dongjiang River in spring.

Like the water samples, low molecular weight PAHs in SPM were also the dominant compounds. However, PAHs in this study are at different levels compared with the previous investigation in other areas. PAHs in SPM in this study were 2 orders of magnitude higher than those of the particulate samples collected from other regions (Table 3 ), such as the Xijiang River $(0.17-58.2 \mathrm{ng} / \mathrm{L})$ [5] and six to seven times higher than York River of the VA Estuary (2.09-123 ng/L) [23]. They are at similar level to the concentrations of PAHs in Pearl River and the Macao Harbor, China (150-431 ng/L) [20] and the Seine River and Estuary, France (2-687 ng/L) [24].

3.2.3. PAHs in the Fish Species. Figure 6 shows the tissue distribution of PAHs and lipid contents in different fish species. Different levels of total PAHs in fish species were 


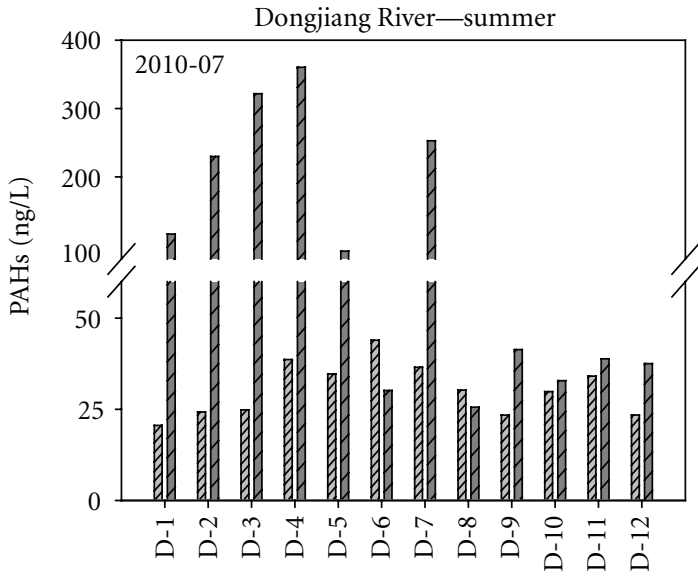

(a)

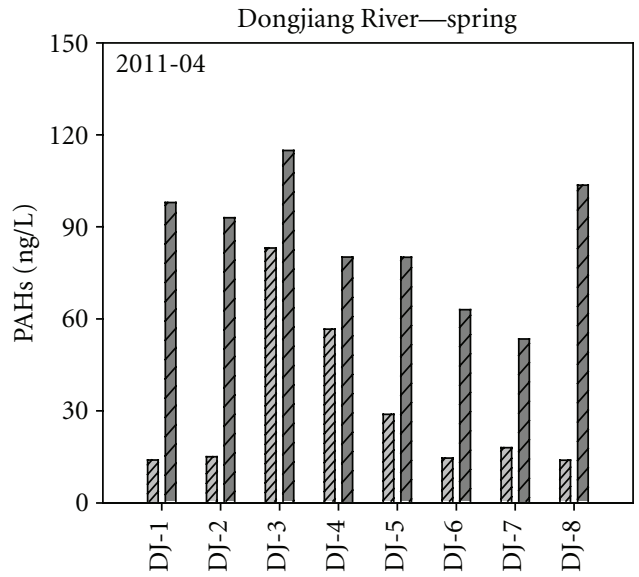

(b)

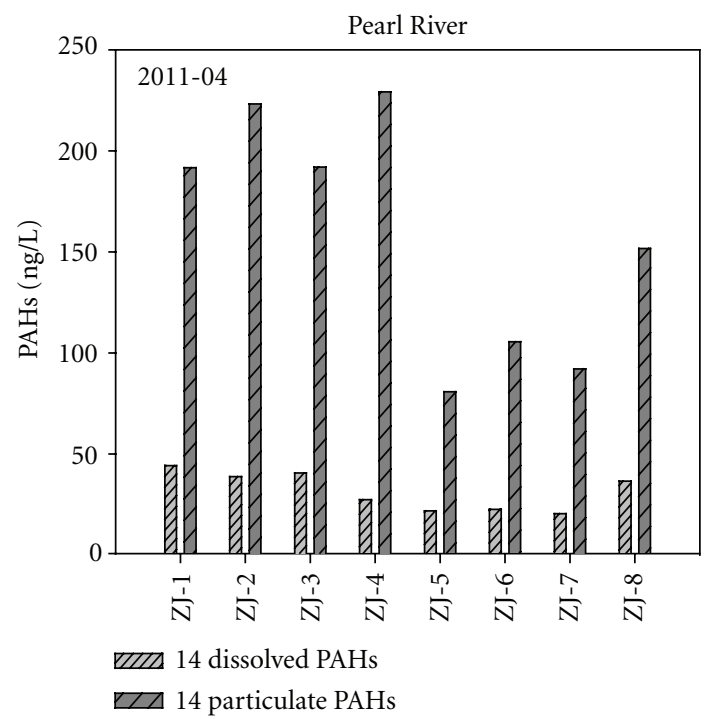

(c)

Figure 4: Spatial distribution of total PAHs in the riverine surface water and the SPM samples from the Pearl River Delta (except for Nap and Phe).

found. The highest concentration of PAHs was detected in red grass carp, ranging from 46.85 to $236.14 \mathrm{ng} / \mathrm{g} \mathrm{dw}$. It was approximately 2 to 3 times higher than other fishes. And the lowest PAHs levels occurred in tilapia (collected in summer), ranging from 14.70 to $80.51 \mathrm{ng} / \mathrm{g}$ dry weight. However, there were no significant differences among the other fish species. In terms of the individual PAHs, low molecular weight PAHs were the major compounds in the fish species, which are similar to those of the water and SPM samples. Compared with PAHs in the muscle (184-194 ng/g dw) and viscera tissues (505-854 ng/g dw) in different sized tilapia reported for Mai Po Marshes by Liang et al. [7], PAHs here both in muscle $(14.55 \mathrm{ng} / \mathrm{g} \mathrm{dw})$ and viscera $(80.51 \mathrm{ng} / \mathrm{g})$ were much lower. This difference might be caused by the feeding habits of different fish species in different aqueous environment.

Significantly different concentrations of PAHs were also observed among fish tissues. Because the visceras of Cirrhinus mrigala, red grass carp, blunt snout bream-2 collected in April 2011, and carp were mashed, only the data of their muscle and gills were present. The highest concentrations of PAHs were found in the visceras, ranging from 80.51 to $180.87 \mathrm{ng} / \mathrm{g}$ dry weight, followed by the concentrations in gills, ranging from 25.43 to $236.14 \mathrm{ng} / \mathrm{g} \mathrm{dw}$, and those in muscle ( 10.52 to $46.85 \mathrm{ng} / \mathrm{g} \mathrm{dw}$ ) are the lowest. The different concentrations of PAHs in fish tissues may be affected by the physical-chemical properties of PAHs, the lipid content, and the uptake capacity of different fish tissues [9].

3.3. Association of PAHs with DOC in Water and with POC in SPM. One of the important factors affecting PAHs in the water and SPM samples was DOC and POC. Correlation analyses between PAHs and DOC or POC were illustrated in Figure 7. Although aqueous PAHs showed no significant correlations with DOC in summer, positive correlations were found between aqueous PAHs and DOC in both the Dongjiang River $(r=0.736, P<0.05)$ and the Pearl River $(r=0.78, P<0.01)$ in spring. For the particulate samples, PAHs in SPM was significantly related to POC in summer 


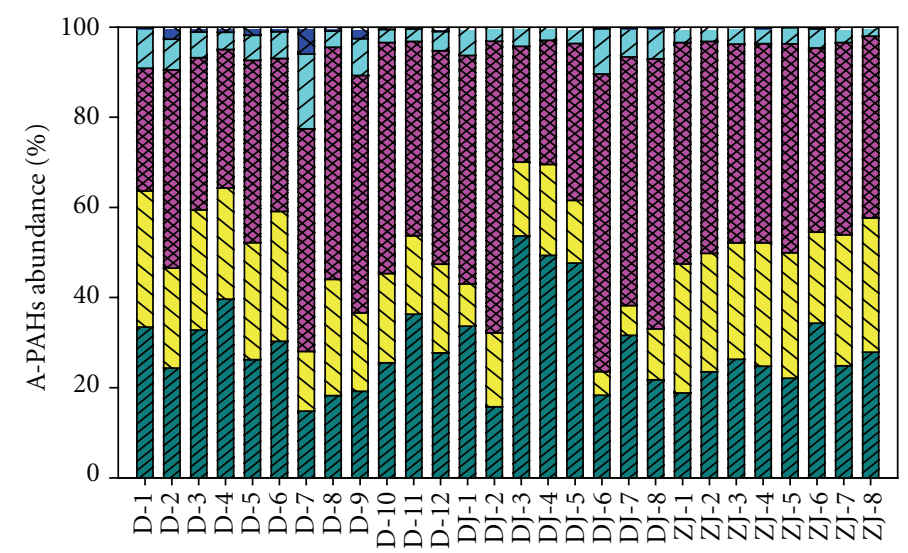

(a)

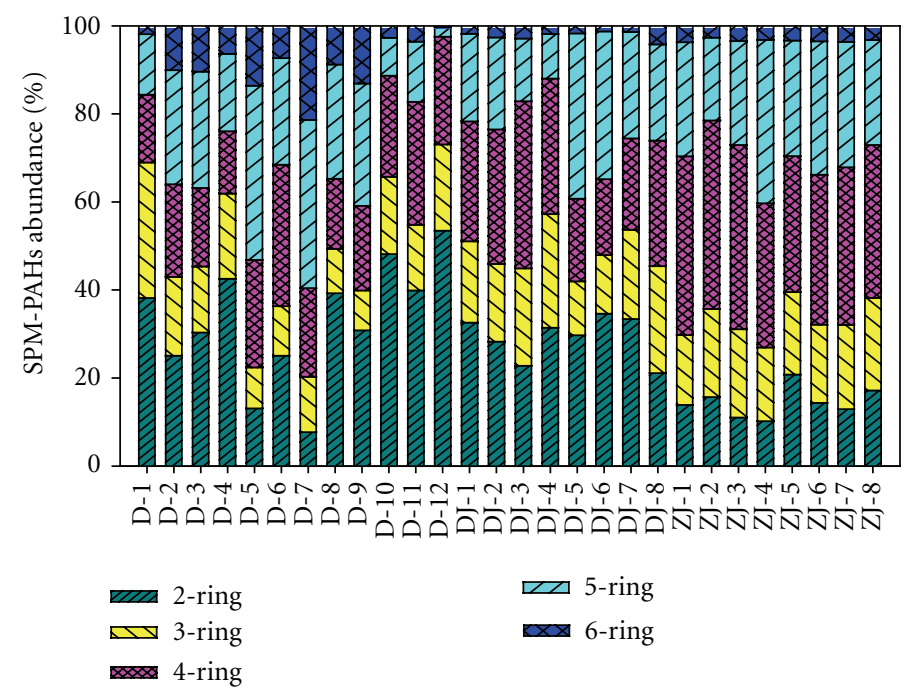

(b)

FIgURE 5: The composition of PAHs in (a) water samples and (b) suspended particular matters samples (both except for Nap and Phe).

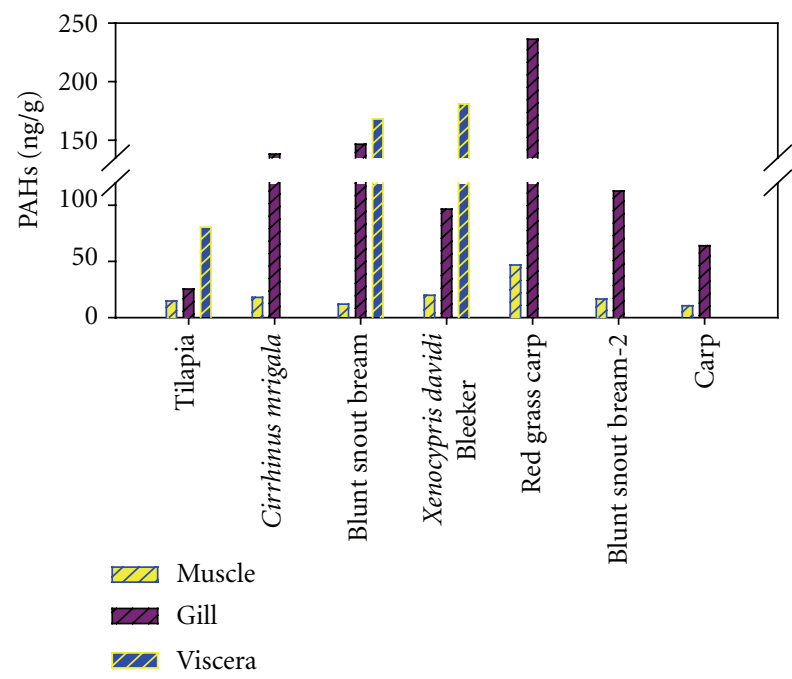

(a)

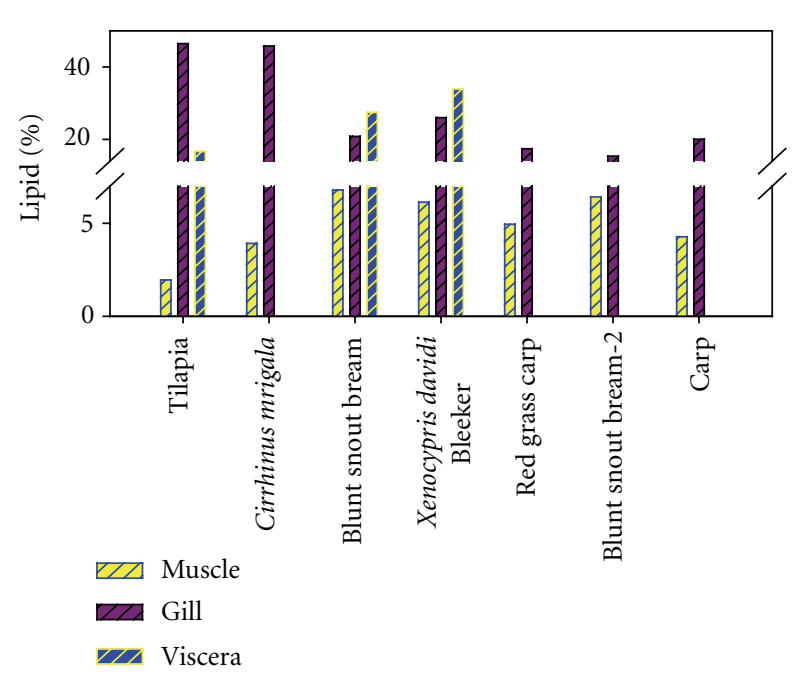

(b)

FIgURe 6: Distribution of total PAHs and lipid (\%) in fish species from the Pearl River Delta. 
TABLE 3: Summary of total PAHs concentration (ng/L) in water and SPM from different sites around the world.

\begin{tabular}{|c|c|c|c|c|}
\hline & Location & Concentration (ng/L) & $N$ & References \\
\hline \multirow{12}{*}{ Water } & Pearl River Delta, China & $11.11-65.21$ & 15 & This study \\
\hline & Xijiang River, China & $21.7-138$ & 15 & Deng et al. [5] \\
\hline & Pearl River and the Macao Harbor, China & $13.64-106.85$ & 15 & Luo et al. [20] \\
\hline & Seine River and Estuary, France & $4-36$ & 11 & Fernandes et al. [24] \\
\hline & Daya Bay, China & $4181-27507$ & 15 & Zhou and Maskaoui [18] \\
\hline & Western Xiamen Sea, China & $106-945$ & 15 & Zhou et al. [33] \\
\hline & Jiulong River Estuary and Western & $6840-25620$ & 15 & Maskaoui et al. [19] \\
\hline & Xiamen Sea, China & & & \\
\hline & Chesapeake Bay, USA & $20-65.7$ & 17 & Gustafson and Dickhut [22] \\
\hline & Baltic Sea & $3.85-14.1$ & 15 & Witt [21] \\
\hline & North Sea & $0.63-3.51$ & 15 & Witt [21] \\
\hline & Pearl River Delta, China & $10.8-323$ & 15 & Wang et al. [14] \\
\hline \multirow{5}{*}{ SPM } & Pearl River Delta China & $34.68-403.12$ & 15 & This study \\
\hline & Xijiang River, China & $0.17-58.2$ & 15 & Deng et al. [5] \\
\hline & Pearl River and the Macao Harbor, China & $73.54-411.51$ & 15 & Luo et al. [20] \\
\hline & York River, VA, Estuary, USA & $2.09-123$ & 20 & Countway et al. [23] \\
\hline & Seine River and Estuary, France & $2-687$ & 11 & Fernandes et al. [24] \\
\hline
\end{tabular}

$N$ : Numbers of PAHs compounds analyzed in each study.

$(r=0.695, P<0.05)$ in Dongjiang River and in both the Pearl River $(r=0.625, P<0.05)$ and Dongjiang River $(r=$ $0.783, P<0.05)$ in spring. The highly significant correlation between PAHs and organic carbon indicated that both DOC and POC are important to the distribution of PAHs in aquatic environment.

Moreover, the slopes in Figure 7 demonstrate the importance of DOC to the association of PAHs. The slopes are $-0.788,12.19$, and $7.63 \mathrm{ng} / \mathrm{mg}$ for DOC, and 50.71, 37.97, and $22.79 \mathrm{ng} / \mathrm{mg}$ for POC in the Dongjiang River in summer, in the Dongjiang River and in the Pearl River in spring, respectively. Hence, PAHs should be greatly affected by POC than by DOC in the targeted river system.

It is also widely acknowledged that $K_{\mathrm{oc}}$ is closely related to $K_{\mathrm{ow}}$ [25]. Hence, hydrophobic compounds such as PAHs with higher $K_{\text {ow }}$ show stronger affinity to POC or DOC. The four dominant PAHs (acenaphthylene, fluorene, fluoranthene, and pyrene) in the dissolved and the particulate phases were normalized by DOC and POC, respectively (Figure 8). It was found that the mean POC-normalized concentrations for Flo, Flu, and Pyr were 21.79, 13.84, and $12.74 \mu \mathrm{g} / \mathrm{g} \mathrm{oc}$, respectively; and the mean DOC-normalized concentrations were $1.57,1.50$, and $2.67 \mu \mathrm{g} / \mathrm{g}$ oc, resp.). The formers were over one order of magnitude higher than the latter ones. And the POC-normalized concentration for Ace $(2.25 \mu \mathrm{g} / \mathrm{g} \mathrm{oc})$ was similar to its DOC-normalized concentration $(2.25 \mu \mathrm{g} / \mathrm{g}$ oc) (Figure 5). As Flo, Flu, and Pyr are hydrophobic nature with $\log K_{\text {ow }}$ of $4.18,4.90$, and 4.88 , they are readily associated with POC and accumulated in SPM. The partitioning patterns of PAHs further reveal that POC and DOC are the most important factors in controlling their distribution, transport, and fate in the surface river water.
3.4. Distribution Coefficients of PAHs between Water and SPM. Distribution of PAHs between SPM and water plays a very important role in the mobility and fate of PAHs in aqueous systems. The most frequently used parameter for evaluating their distribution is the organic carbon-normalized particlewater partitioning coefficients $K_{\mathrm{oc}}$, which were calculated as follows:

$$
K_{\mathrm{oc}}=\frac{C_{s} / C_{w}}{f_{\mathrm{oc}}}
$$

where $C_{s}$ is the solid phase concentration $(\mathrm{ng} / \mathrm{g}), C_{w}$ is the aqueous phase concentration $(\mathrm{ng} / \mathrm{mL})$, and $f_{\mathrm{oc}}$ is the mass fraction of organic carbon in the particle.

From Figure 9, $\log K_{\mathrm{oc}} \mathrm{mL} / \mathrm{g}$ was significantly related to $\log K_{\text {ow }}$ for the samples collected both from the Dongjiang River $(r=0.577)$ and the Pearl River $(r=0.897)$, implying that PAHs with high hydrophobicity can be adsorbed on SPM more easily. The free energy relationship between $\log K_{\mathrm{ow}}$ and $\log K_{\mathrm{oc}}$ was established in Figure 9. The observed equation for PAHs is similar to the previous investigation on the $\log K_{\mathrm{oc}}-\log K_{\mathrm{ow}}$ regression for PAHs in the water of the PRD [20].

From the slope of the equation in Figure 9, the lipophilicity of SPM relative to the reference octanol/water system may be inferred. The slope in this study is lower than the value listed in Table 4, suggesting that the lipophilicity of SPM in this is relatively low.

\subsection{Bioconcentration of PAHs in Fish Species}

3.5.1. Effects of Lipid on PAHs Distribution. Lipid plays an important role in the accumulation of PAHs in aquatic 


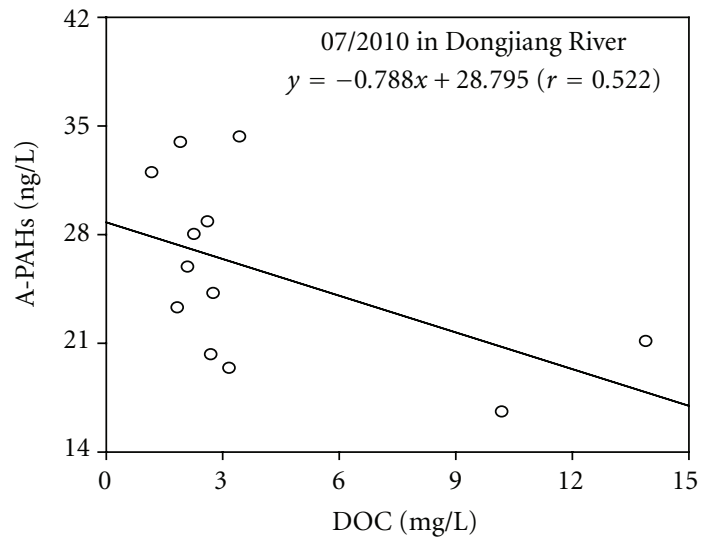

(a)

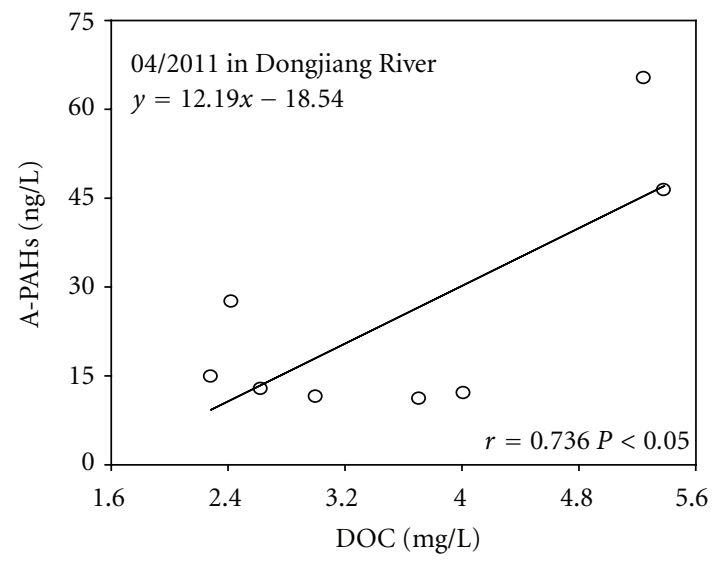

(c)

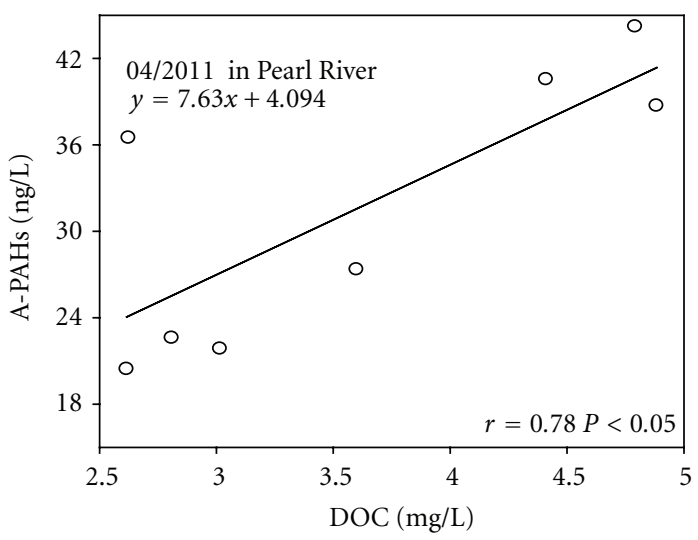

(e)

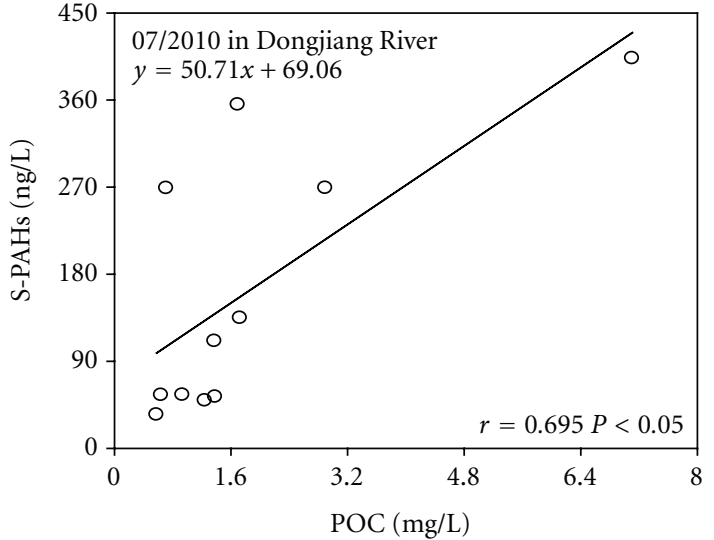

(b)

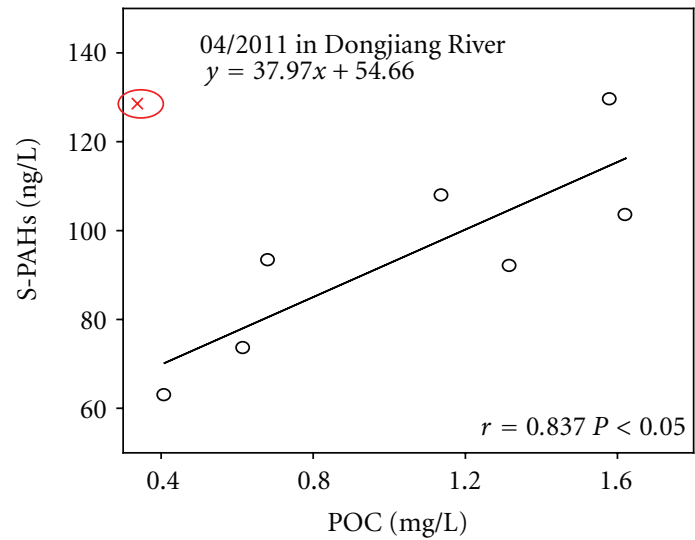

(d)

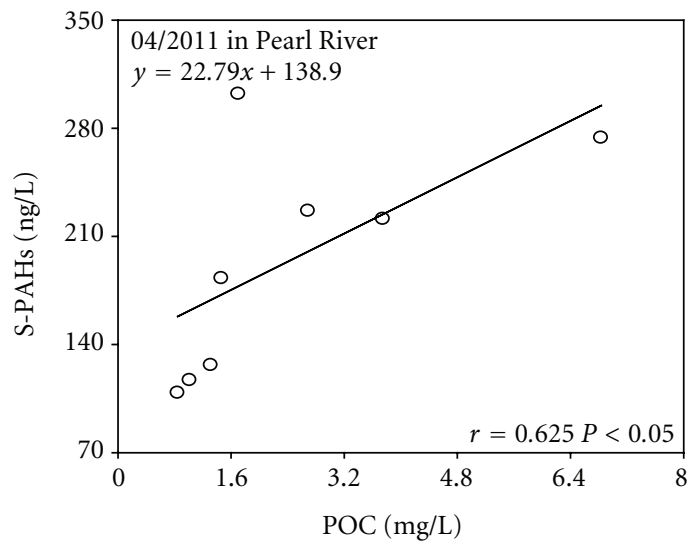

(f)

Figure 7: Correlations of 14 PAHs with DOC in water samples and with POC in the SPM samples. A-PAHs and S-PAHs correspond to the dissolved PAHs and particulate PAHs, respectively.

organisms, since PAHs are easily accumulated in lipid-rich tissue of fish. The lipid contents in different tissues of each fish species are shown in Figure 6. The highest lipid contents were presented in the gill tissues, ranging from $15.3 \%$ in blunt snout bream-2 (collected in spring) to $46.5 \%$ in tilapia with an average percentage of $27.4 \% \mathrm{dw}$, followed by those in viscera tissues ranging from $16.68 \%$ in tilapia to $33.93 \%$ in xenocypris davidi Bleeker with the average percentage of
$26.03 \%$. The lowest lipid contents were found in the muscle tissues, varying from $1.96 \%$ in tilapia to $6.79 \%$ in blunt snout bream with an average percentage of $4.7 \%$. Relationship between PAHs and lipids in different tissues of fish species was showed in Figure 10. Significant positive correlations between total PAHs and lipids in different tissues of fishes from Dongjiang River were obtained $(r=0.859, P<$ $0.0001)$. 
TABLE 4: Correlations of $\log K_{\mathrm{oc}}$ against $\log K_{\mathrm{ow}}$ values determined for selected PAHs. $a, b$, and $R^{2}$ correspond, respectively to slope, intercept, and square determination coefficient.

\begin{tabular}{lcccc}
\hline Sorbent & Sorption experiment & $a$ & $b$ & $R^{2}$ \\
\hline Coarse size fraction in sediments [34] & laboratory & 1.00 & -0.21 & 1.00 \\
Soil and sediments [35] & laboratory & 1.00 & -0.317 & 0.98 \\
Seine River suspensions [24] & In situ & 0.70 & 0.75 & 3.41 \\
SPM of Pearl River Delta [20] & In situ & 0.58 & 1.68 & 0.95 \\
SPM of Xijiang River [5] & In situ & 0.71 & 5.39 & 0.95 \\
SPM of Dongjiang River (This study) & In situ & 0.51 & 4.03 & $0.57(r)$ \\
SPM of Pearl River (This study) & In situ & & $0.897(r)$ \\
\hline
\end{tabular}

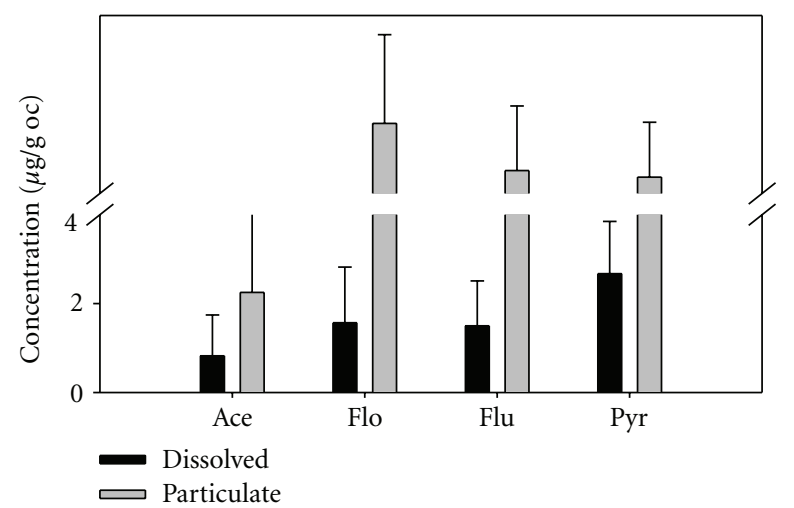

FIGURE 8: Organic carbon-normalized concentrations of Ace, Flo, Flu, and Pyr in the river water and the SPM samples.

3.5.2. Bioconcentration Factors (BCFs) in Fish Tissues. In order to compare between the bioaccumulation patterns among individual PAHs in fish, BCFs were calculated and plotted. BCF in the viscera of tilapia was observed to increase with the increasing $K_{\mathrm{ow}}\left(\log \mathrm{BCF}=0.507 \log K_{\mathrm{ow}}+1.631\right.$, $r=0.883$ ) (Figure 11(a)). This observation is consistent with other investigation on bioconcentration [26], suggesting that the bioaccumulation of organic chemicals in biota increases with the increasing of $\log K_{\text {ow }}$. However, measured BCF values tend to decline below the true equilibrium condition as the $K_{\text {ow }}$ of the chemical increases.

$\mathrm{BCF}$ will reach the maximum value when $\log K_{\mathrm{ow}}$ reaches 5-7 and then decreases when $\log K_{\text {ow }}$ is higher than 7. Except for the viscera of tilapia, most of the BCF values in different fish tissues follow this trend as demonstrated in Figure 11(b). This difference may depend on living habitat and trophic levels of fish and environmental behaviors of PAHs. The bioavailability, uptake, and fate of PAHs by aquatic organisms from contaminated media (water, sediments, and food) were also affected by a variety of physical (e.g., lipophilicity, temperature, etc.) and biological parameters. As a general rule, water is dominant pathway of exposure for fish if $\log K_{\text {ow }}$ of organic compounds are lower than 5, while sediment particles can be used for some fish species such as food and can contribute substantially to bioaccumulation for PAHs with $\log K_{\text {ow }}$ higher than 5 [27]. As Tilapia used to live in the bottom layer of aquatic ecosystem and in sediments PAHs in sediments may contribute to accumulation in tilapia via the dietary route and exchange with water through gills.
The previous result indicates that BCF is quite different due to the diversity of fish species.

The previous result is consistent with previous studies which illustrated that the relationship between $K_{\mathrm{ow}}$ and bioconcentration appeared to be relatively complex [28]. For fish with low feeding rates, the bioaccumulation of nonpolar organic compounds with $\log K_{\text {ow }}$ ranging from 2 to 6.5 is mainly determined by exchange across the gills. However, dietary uptake seems negligible because of poor absorption efficiency and rapid metabolism rates [29, 30]. For nonmetabolized PAHs, less bioaccumulation of organic compounds would appear in small fishes due to the higher oxygen uptake, which leads to much loss than uptake of organic compound, than in large ones [29]. It was also suggested that bioaccumulation of low $K_{\mathrm{ow}}$ PAHs (such as naphthalene) was high due to higher gill transfer efficiencies, and that of high $K_{\text {ow }}$ was low because of enhanced biotransformation and decreased gut assimilation in fish $[31,32]$. Moreover, the physicochemical properties of a chemical, the physiological components of the uptake process, biotransformation, blood flow, and fatty acid composition and lipid content in aquatic animals could all affect the uptake and accumulation of organic chemicals for fishes [28]. All of those factors contribute to the unpredictability of the bioaccumulation of POPs in fishes.

\section{Conclusion}

The spatial distribution and bioconcentration of PAHs in the water, SPM, and fish species from the Pearl River Delta were 


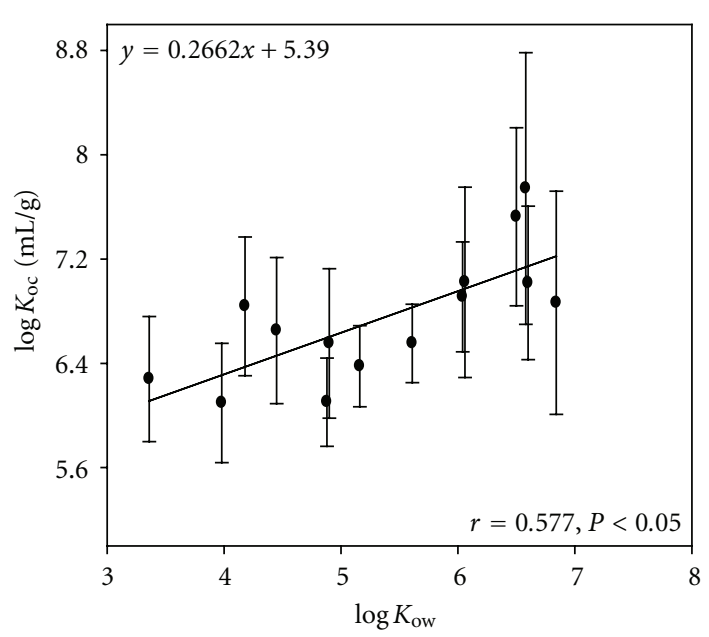

(a) Dongjiang

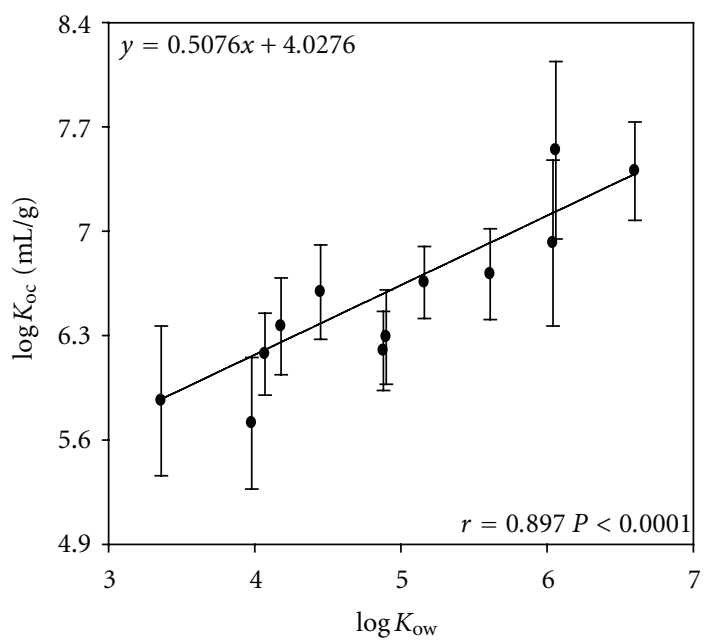

(b) Pearl River

Figure 9: Relationship between $\log K_{\mathrm{oc}}$ and $\log K_{\mathrm{ow}}$ for PAHs.

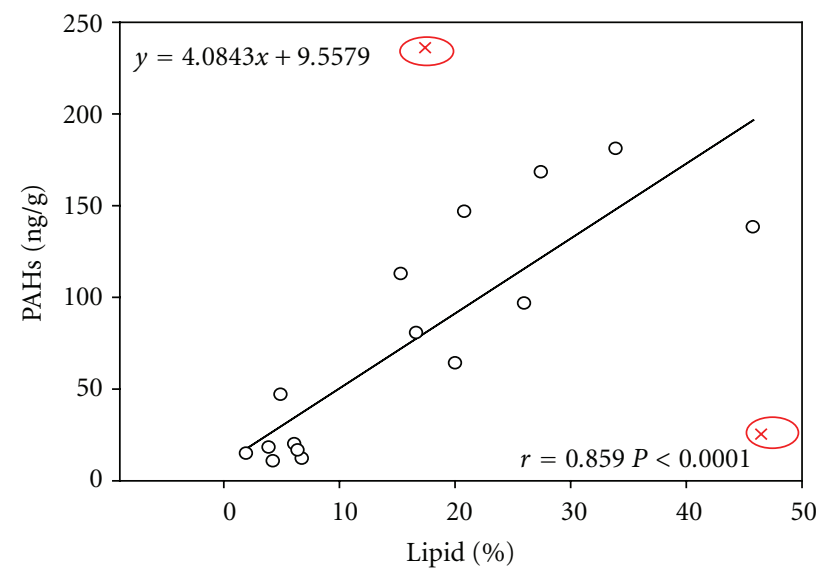

FIGURE 10: Correlations of lipid with PAHs in tissues of fishes. The two red points represent the samples (gill of tilapia and gill of red grass carp) which are not included in the correlation analysis.

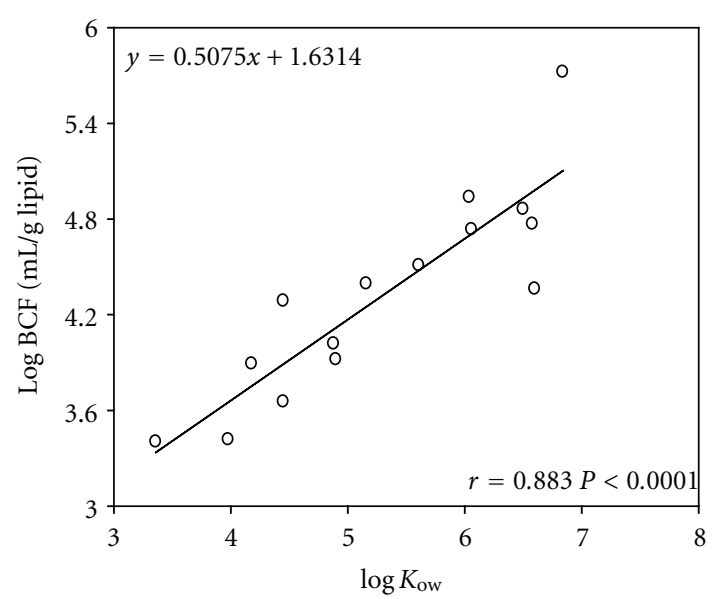

(a) Tilapia-viscera

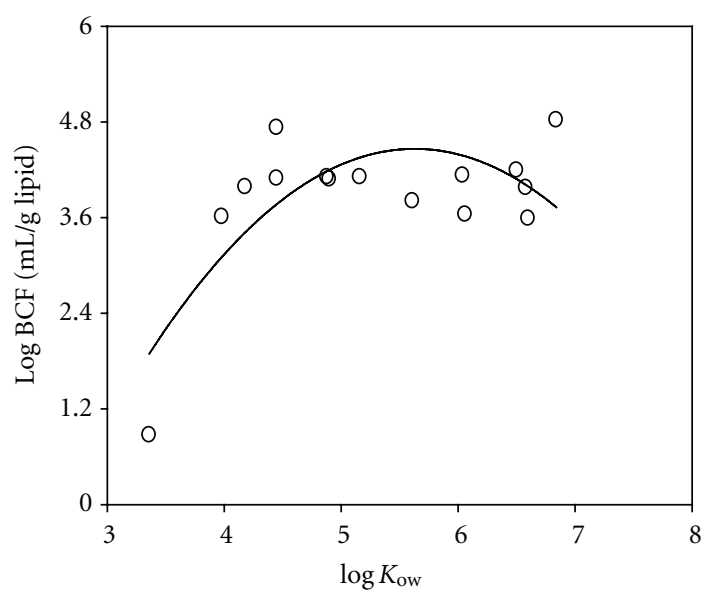

(b) Blunt snout bream—viscera

FIGURE 11: Correlations of $\log K_{\text {ow }}$ with $\log$ BCF of viscera in tilapia (a) and blunt snout bream (b). 
examined. Aquatic chemical data were also determined. In both the dissolved and the particulate phases, the low molecular weight PAHs were the dominant components. Positive correlation were found between aqueous PAHs and DOC as well as particulate PAHs and POC, indicating the importance of DOC and POC to the distribution of PAHs in the aquatic environment. The in-situ partitioning coefficients $\left(\log K_{\mathrm{oc}}\right.$, $\mathrm{mL} / \mathrm{g}$ ) for the samples were related to $\log K_{\text {ow }}$. The relative lipophilicity of SPM could be evaluated by the slope of the observed regression equation. PAHs showed significant correlations with lipids in different tissues of fishes. BCF in the viscera of tilapia was positively related to $\log K_{\mathrm{ow}}$. But BCF values in most of the fish samples were found to reach the maximum value when $\log K_{\text {ow }}$ reaches 5-7 and then decrease when $\log K_{\text {ow }}$ is higher than 7 . The different distribution of PAHs among the fish species and their tissues were affected by $\log K_{\text {ow }}$ of PAHs and the lipid contents in fish tissues.

\section{Acknowledgments}

The investigation was financially supported by the Key Field Project of the Knowledge Innovation Program, Chinese Academy of Sciences (Y234081A07), the "Team Program" Project and a general project of the National Natural Science Foundation of China (Project nos. 41121063 and 40972222), and the Earmarked Foundation of the State Key Laboratory (SKLOG2009A04), the State Science and Technology Ministry of China, which were much appreciated. This is contribution no. IS-1597 from GIGCAS. The authors would like also to thank two anonymous reviewers for the comments for improvement of the paper.

\section{References}

[1] C. Seruto, Y. Sapozhnikova, and D. Schlenk, "Evaluation of the relationships between biochemical endpoints of $\mathrm{PAH}$ exposure and physiological endpoints of reproduction in male California Halibut (Paralichthys californicus) exposed to sediments from a natural oil seep," Marine Environmental Research, vol. 60, no. 4, pp. 454-465, 2005.

[2] M. Yamada, H. Takada, K. Toyoda et al., "Study on the fate of petroleum-derived polycyclic aromatic hydrocarbons (PAHs) and the effect of chemical dispersant using an enclosed ecosystem, mesocosm," Marine Pollution Bulletin, vol. 47, no. 1-6, pp. 105-113, 2003.

[3] D. M. Kim, M. J. Heo, S. J. Oh et al., "Prediction of the transport and fate of polycyclic aromatic hydrocarbons (PAHs) in Masan Bay, South Korea," Journal of the Faculty of Agriculture Kyushu University, vol. 56, no. 2, pp. 299-305, 2011.

[4] Y. W. Qiu, G. Zhang, G. Q. Liu, L. L. Guo, X. D. Li, and O. Wai, "Polycyclic aromatic hydrocarbons (PAHs) in the water column and sediment core of Deep Bay, South China," Estuarine, Coastal and Shelf Science, vol. 83, no. 1, pp. 60-66, 2009.

[5] H. M. Deng, P. A. Peng, W. L. Huang, and J. Song, "Distribution and loadings of polycyclic aromatic hydrocarbons in the Xijiang River in Guangdong, South China," Chemosphere, vol. 64, no. 8, pp. 1401-1411, 2006.

[6] X. J. Luo, S. J. Chen, B. X. Mai, Q. S. Yang, G. Y. Sheng, and J. $\mathrm{M}$. Fu, "Polycyclic aromatic hydrocarbons in suspended particulate matter and sediments from the Pearl River Estuary and adjacent coastal areas, China," Environmental Pollution, vol. 139, no. 1, pp. 9-20, 2006.
[7] Y. Liang, M. F. Tse, L. Young, and M. H. Wong, "Distribution patterns of polycyclic aromatic hydrocarbons (PAHs) in the sediments and fish at Mai Po Marshes Nature Reserve, Hong Kong," Water Research, vol. 41, no. 6, pp. 1303-1311, 2007.

[8] X. Z. Meng, E. Y. Zeng, L. P. Yu, B. X. Mai, X. J. Luo, and Y. Ran, "Persistent halogenated hydrocarbons in consumer fish of China: regional and global implications for human exposure," Environmental Science and Technology, vol. 41, no. 6, pp. 1821-1827, 2007.

[9] F. L. Xu, W. J. Wu, J. J. Wang et al., "Residual levels and health risk of polycyclic aromatic hydrocarbons in freshwater fishes from Lake Small Bai-Yang-Dian, Northern China," Ecological Modelling, vol. 222, no. 2, pp. 275-286, 2011.

[10] J. M. Fu, G. Y. Sheng, Y. Chen et al., "Preliminary study of organic pollutants in air of guangzhou, Hong Kong, and Macao," ACS Symposium Series, vol. 671, pp. 164-176, 1997.

[11] Y. H. Yanhong, G. Y. Sheng, J. M. Fu, and Y. S. Min, "Organochlorinated compounds in waters of the Pearl River Delta region," Environmental Monitoring and Assessment, vol. 44, no. 1-3, pp. 569-575, 1997.

[12] Y. Guo, X. Z. Meng, H. L. Tang, and E. Y. Zeng, "Tissue distribution of organochlorine pesticides in fish collected from the Pearl River Delta, China: implications for fishery input source and bioaccumulation," Environmental Pollution, vol. 155, no. 1, pp. 150-156, 2008.

[13] E. Martinez, M. Gros, S. Lacorte, and D. Barceló, "Simplified procedures for the analysis of polycyclic aromatic hydrocarbons in water, sediments and mussels," Journal of Chromatography A, vol. 1047, no. 2, pp. 181-188, 2004.

[14] J. Z. Wang, Y. F. Guan, H. G. Ni, X. L. Luo, and E. Y. Zeng, "Polycyclic aromatic hydrocarbons in riverine runoff of the Pearl River Delta (China): concentrations, fluxes, and fate," Environmental Science and Technology, vol. 41, no. 16, pp. 5614-5619, 2007.

[15] A. E. Greenberg, L. S. Clescerl, and A. D. Eaton, Standard Methods For the Examination of Water and Wastewater, American Public Health Association, Washington, DC, USA, 20th edition, 1998.

[16] J. Dachs, S. J. Eisenreich, J. E. Baker, F. C. Ko, and J. D. Jeremiason, "Coupling of phytoplankton uptake and air-water exchange of persistent organic pollutants," Environmental Science and Technology, vol. 33, no. 20, pp. 3653-3660, 1999.

[17] M. Söderström, K. Nylund, U. Järnberg, G. Lithner, G. Rosén, and H. Kylin, "Seasonal variations of DDT compounds and PCB in a eutrophic and an oligotrophic lake in relation to algal biomass," Royal Swedish Academy of Sciences, vol. 29, no. 4-5, pp. 230-237, 2000.

[18] J. L. Zhou and K. Maskaoui, "Distribution of polycyclic aromatic hydrocarbons in water and surface sediments from Daya Bay, China," Environmental Pollution, vol. 121, no. 2, pp. 269281, 2003.

[19] K. Maskaoui, J. L. Zhou, H. S. Hong, and Z. L. Zhang, "Contamination by polycyclic aromatic hydrocarbons in the Jiulong River Estuary and Western Xiamen Sea, China," Environmental Pollution, vol. 118, no. 1, pp. 109-122, 2002.

[20] X. J. Luo, B. X. Mai, Q. S. Yang, J. M. Fu, G. Y. Sheng, and Z. S. Wang, "Polycyclic aromatic hydrocarbons (PAHs) and organochlorine pesticides in water columns from the Pearl River and the Macao harbor in the Pearl River Delta in South China," Marine Pollution Bulletin, vol. 48, no. 11-12, pp. 1102-1115, 2004.

[21] G. Witt, "Polycyclic aromatic hydrocarbons in water and sediment of the Baltic Sea," Marine Pollution Bulletin, vol. 31, no. 4-12, pp. 237-248, 1995. 
[22] K. E. Gustafson and R. M. Dickhut, "Distribution of polycyclic aromatic hydrocarbons in southern Chesapeake Bay surface water: evaluation of three methods for determining freely dissolved water concentrations," Environmental Toxicology and Chemistry, vol. 16, no. 3, pp. 452-461, 1997.

[23] R. E. Countway, R. M. Dickhut, and E. A. Canuel, "Polycyclic aromatic hydrocarbon $(\mathrm{PAH})$ distributions and associations with organic matter in surface waters of the York River, VA Estuary," Organic Geochemistry, vol. 34, no. 2, pp. 209-224, 2003.

[24] M. B. Fernandes, M. A. Sicre, A. Boireau, and J. Tronczynski, "Polyaromatic hydrocarbon $(\mathrm{PAH})$ distributions in the Seine River and its estuary," Marine Pollution Bulletin, vol. 34, no. 11, pp. 857-867, 1997.

[25] L. P. Burkhard, "Estimating dissolved organic carbon partition coefficients for nonionic organic chemicals," Environmental Science and Technology, vol. 34, no. 22, pp. 4663-4668, 2000.

[26] J. P. Connolly and C. J. Pedersen, "A thermodynamic-based evaluation of organic chemical accumulation in aquatic organisms," Environmental Science and Technology, vol. 22, no. 1, pp. 99-103, 1988.

[27] P. F. Landrum, "Bioavailability and toxicokinetics of polycyclic aromatic hydrocarbons sorbed to sediments for the amphipod pontoporeia hoyi," Environmental Science and Technology, vol. 23, pp. 588-595, 1989.

[28] M. G. Barron, "Bioconcentration: will water-borne organic chemicals accumulate in aquatic animals?" Environmental Science \& Technology, vol. 24, no. 11, pp. 1612-1618, 1990.

[29] D. J. Randall, D. W. Cornell, R. Yang, and S. S. Wu, "Concentrations of persistent lipophilic compounds in fish are determined by exchange across the gills, not through the food chain," Chemosphere, vol. 37, no. 7, pp. 1263-1270, 1998.

[30] B. C. Kelly, F. A. P. C. Gobas, and M. S. McLachlan, "Intestinal absorption and biomagnification of organic contaminants in fish, wildlife, and humans," Environmental Toxicology and Chemistry, vol. 23, no. 10, pp. 2324-2336, 2004.

[31] R. V. Thomann and J. Komlos, "Model of biota-sediment accumulation factor for polycyclic aromatic hydrocarbons," Environmental Toxicology and Chemistry, vol. 18, no. 5, pp. 1060-1068, 1999.

[32] R. V. Thomann, J. P. Connolly, and T. F. Parkerton, "An equilibrium model of organic chemical accumulation in aquatic food webs with sediment interaction," Environmental Toxicology and Chemistry, vol. 11, no. 10, p. 1509, 1992.

[33] J. L. Zhou, H. Hong, Z. Zhang, K. Maskaoui, and W. Chen, "Multiphase distribution of organic micropollutants in Xiamen Harbour, China," Water Research, vol. 34, no. 7, pp. 2132-2150, 2000.

[34] S. W. Karickhoff, D. S. Brown, and T. A. Scott, "Sorption of hydrophobic pollutants on natural sediments," Water Research, vol. 13, no. 3, pp. 241-248, 1979.

[35] J. C. Means, "Sorption of polynuclear aromatic hydrocarbons by sediments and soils 1," Environmental Science and Technology, vol. 14, no. 12, pp. 1524-1528, 1980. 


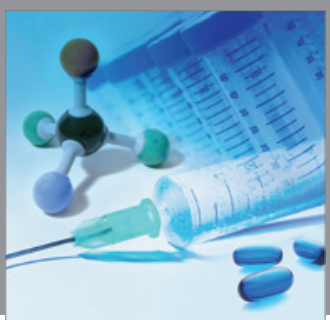

International Journal of

Medicinal Chemistry

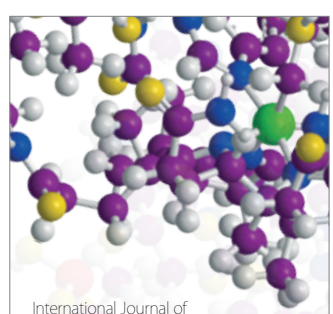

Carbohydrate Chemistry

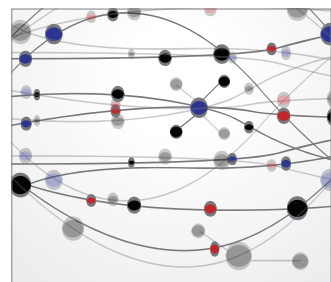

The Scientific World Journal
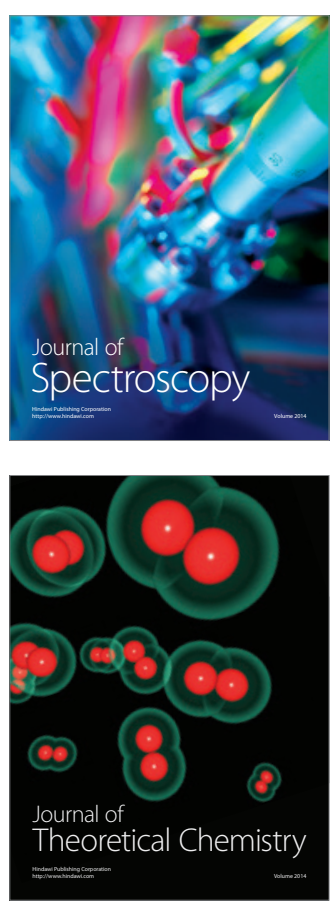
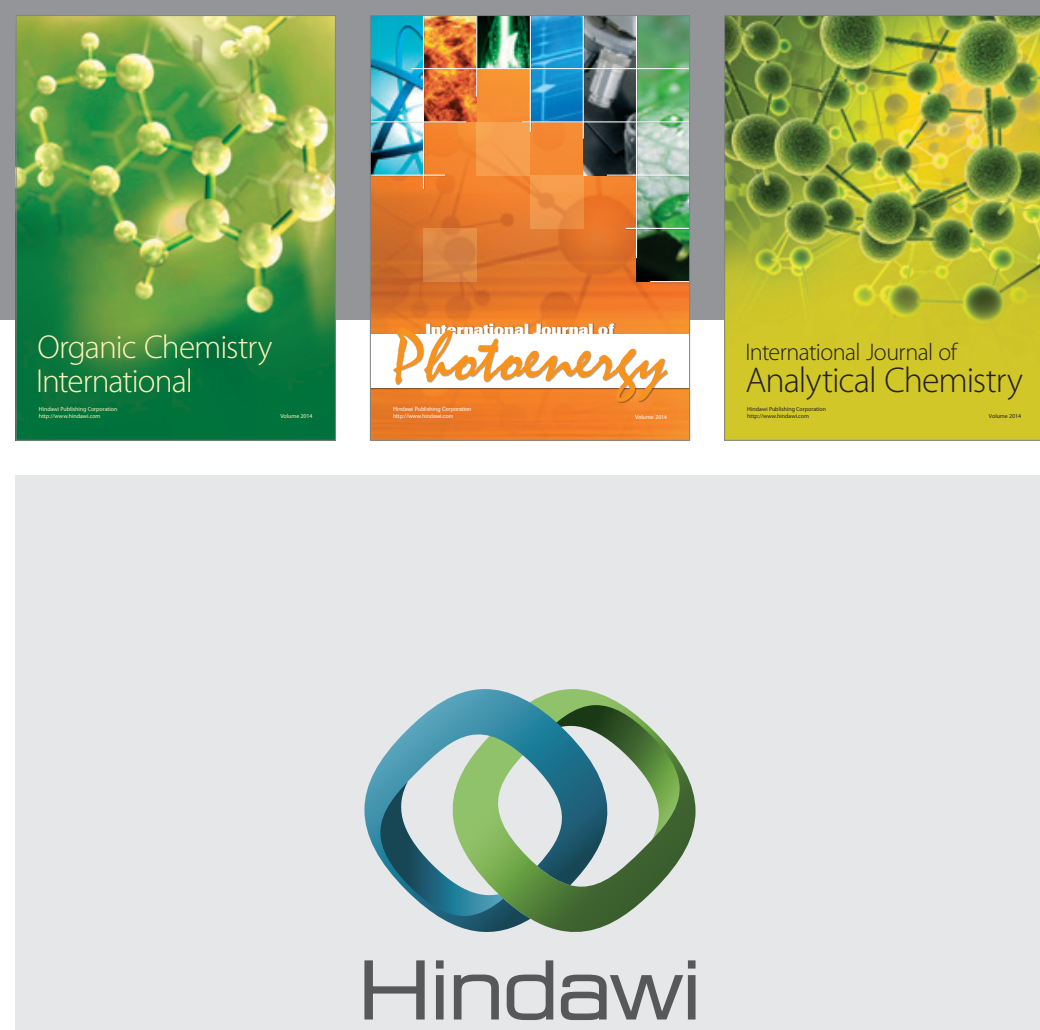

Submit your manuscripts at

http://www.hindawi.com
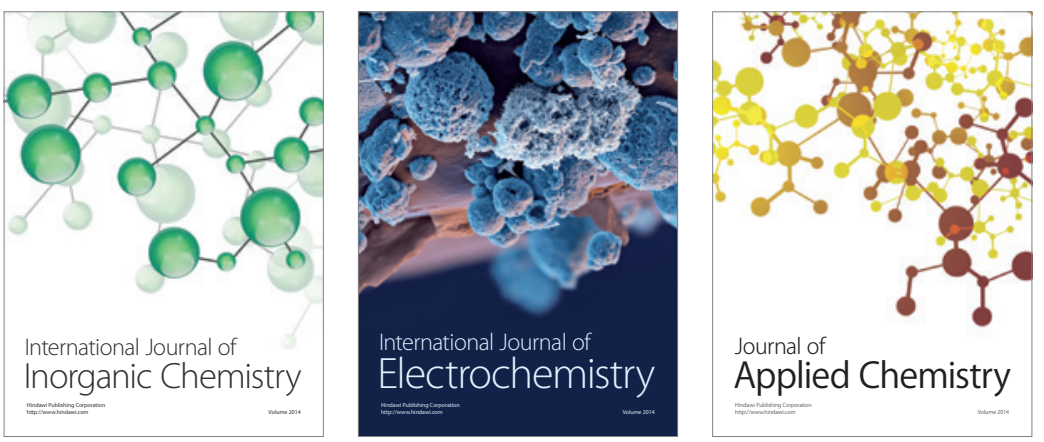

Journal of

Applied Chemistry
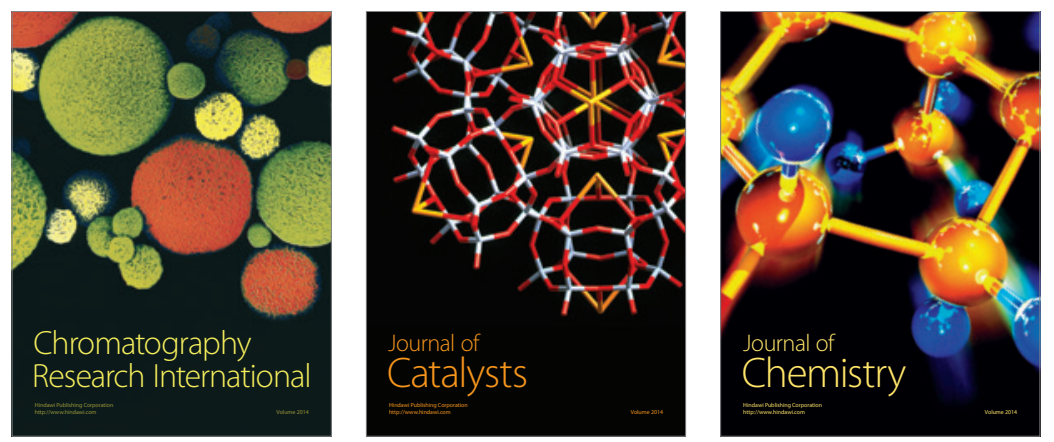
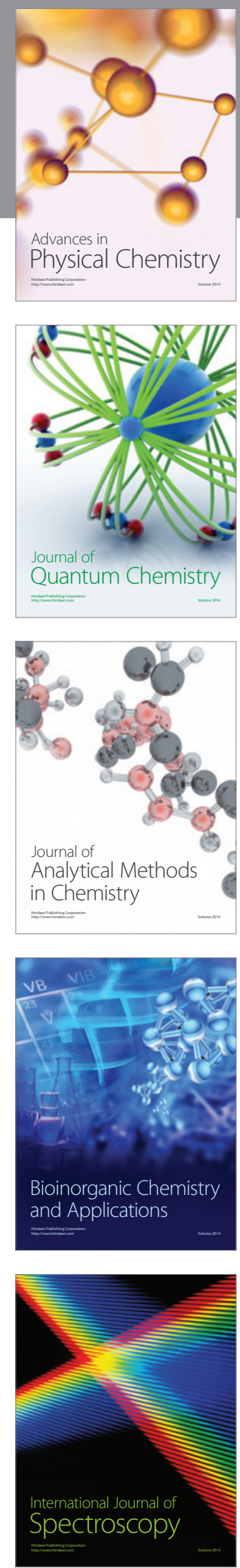